\title{
Olumsuz Güncel Gelişmelerin ve Krizlerin Türk Turizmine Etkileri: Profesyonel Turist Rehberlerinin Değerlendirmeleri ve Sektörel Çözüm Önerileri
}

\author{
İlker ŞAHİN*, F. Özlem GÜZEL**
}

Öz

Arap Baharı neticesinde geçtiğimiz yıllarda siyasi, ekonomik ve sosyolojik açıdan büyük değișimler yaşayan Ortadoğu ülkelerine coğrafi ve kültürel yakınlığı bulunan Türkiye, 2020 yılında Çin-Vuhan kentinden dünyaya yayılan ölümcül yeni tip koronavirüs (COVID-19) salgınıyla mücadele etmiştir. Son dönemde meydana gelen güncel gelişme, pandemi ve krizler başta turizm olmak üzere birçok sektörü olumsuz etkilemiştir. Bu noktadan hareketle, araştırmanın temel amacı kokartlı turist rehberlerinin olumsuz güncel gelişmeler karşısında turizmin karakteristik özelliklerini nasıl değerlendirdiklerini ve hangi alternatif çözüm önerilerini sunduklarını ortaya çıkarmaktır. Keşifsel bakış açısını benimseyerek bütüncül çoklu durum deseninde tasarlanan bu çalışmada nitel araştırma yöntemi kullanılmıştır. Bu amaç doğrultusunda ülke imajının turistler nezdinde șekillenmesine büyük rol oynayan turist rehberleri nitel araştırmanın örneklemini olușturmaktadır. 65 profesyonel turist rehberinden görüşme tekniğiyle elde edilen veriler, kodlama metodu kullanılarak betimsel analize tabi tutulmuştur. Bulgulara göre, olumsuz güncel gelişmeler ve krizler karşısında turizmin "kırılgan yapı, rekabetçi yapı, ikame edilebilirlik özelliği ve ülke imajının zedelenmesi" olmak üzere dört yapısal özellik gösterdiği ortaya çıkmıştır. Rehberlerin turizm sektöründe alınması gereken önlemlere ilişkin "güvenlik vaadi, tanıtım faaliyetleri, destinasyon markalaşması ve hedef pazar çalışmaları" bașta olmak üzere toplam 14 ana tema ile bunlara bağlı 64 alt temada uygulamaya dönük sektörel çözüm önerileri sundukları ortaya çıkmıștır.

Anahtar Kelimeler: Turizmde Kriz, Politik Kriz, Turizmde Sektörel Öneriler, Turist Rehberleri, Koronavirüs.

\footnotetext{
Özgün Araştırma Makalesi (Original Research Article)

Geliş/Received: 18.03 .2019

Kabul/Accepted: 13.04 .2020

DOI: https://dx.doi.org/10.17336/igusbd.541284

* Arş. Gör., Akdeniz Üniversitesi, Turizm Fakültesi, Turizm Rehberliği Bölümü, Antalya, Türkiye, E-posta: ilkersahin@akdeniz.edu.tr, ilkersahin1985@hotmail.com ORCID https://orcid.org/0000$\underline{0002-0516-4675}$

** Doç. Dr., Akdeniz Üniversitesi, Turizm Fakültesi, Turizm Rehberliği Bölümü, Antalya, Türkiye, E-posta: ozlemguzel@akdeniz.edu.tr; ozlemmguzel@hotmail.com ORCID https://orcid.org/0000$\underline{0003-0081-3530}$
} 


\title{
The Impacts of Negative Current Incidents and Crises on Tourism Sector: Evaluations and Sectoral Solution Offers by Professional Tourist Guides
}

\begin{abstract}
Having geographical and cultural proximity to the Middle East countries undergoing great deal of political, economic and sociological changes in the last years as a result of 'Arab Spring', as well as struggling with China-Wuhan-originated deadly worldwide coronavirus (COVID19) pandemic in 2020, Turkey faced with many problems in many sectors particularly in tourism as a result of current incidents and unexpected crises. From this point of view, the main purpose of this research is to reveal how the tourist guides assess the characteristics of tourism sector and which alternative solutions they suggest against the current events. The qualitative research method is adopted in the exploratory study using a holistic multiple case pattern. The data obtained from the interviews with 60 professional tourist guides were subjected to descriptive content analysis using the coding method. According to the findings "sensitive structure, competitive structure, substitutability and damage to the country image were found out to be four main characteristics of tourism industry. Practical solution proposals by guides associated with tourism industry have been emerged in a total of 14 themes with 64 subthemes.
\end{abstract}

Keywords: Crisis in Tourism, Political Crisis, Solution Proposals in Tourism, Tourist Guides, Coronavirus.

\section{Giriș}

Olumsuz bir durumu ya da olumsuz sonuçlar doğuran dönemsel zorlu bir süreci ifade eden krizler, her ne kadar yaşanması pek arzu edilmese de belirli dönemlerde ansızın sahneye çıkarak ardında telafisi uzun zaman alan derin izler bırakmaktadır. Günlük yaşamın her alanında ortaya çıkabilen krizler, tıpta bir organda aniden meydana gelen ve yaşamsal tehlikeye neden olabilen fizyolojik bir bozukluğu; ekonomide beklenmeyen bir şekilde borsa endeksinin düşmesi, enflasyonun sürekli olarak yükselmesi, bir mal veya hizmetin kıt hale gelmesi veya resmi parada yaşanan hızlı değer kayıplarını ifade ederken; politikada ise aniden ortaya çıkan, uluslararası diplomatik ilișkileri ve siyasi dengeleri alt üst ederek ülkede istikrarsızlığa neden olan her türlü olumsuz durumu tanımlamak için kullanılmaktadır (Anderson, 2006; Glaesser, 2006; Laws ve Prideaux, 2005; Ritchie, 2004; Faulkner; 2001; Fink, 1986). Meydana geliș şekli, süresi, etki gücü, toplumsal algılanıșı veya ilișkilendirildiği olumsuz anlam her ne olursa olsun krizler, meydana getirdiği olumsuz yönlü rüzgârla kitleleri etkisi altına alarak emek yoğun bir sektör olan, güven, mutlu anılar, farklı ve unutulmaz deneyimler üzerine kurulu olan turizm endüstrisinde olumsuz bir atmosfer yaratmaktadır. Laws ve Prideaux (2005) turizmde krizi, mevcut olumlu durumu aniden tersine çeviren ve destinasyonlarda adeta şok etkisi yaratarak durgunluk sürecini beraberinde getiren öngörülmesi güç bir dönem olarak ele almakta; McKercher ve Hui (2004) ise turizmde yaşanan krizleri belirli olayların bir sonucu olarak meydana gelen, turizm ve konaklama endüstrisine zarar veren, önlenmesi zor kaçınılmaz gelişmeler olarak değerlendirmektedir. Sönmez ve Tarlow'a (1997) göre turizmde krizler, normal işleyişi ve turizmle bağlantılı iş kollarını tehdit etmekte; güvenlik, turistik çekicilik, huzur ortamı ve benzeri konularda destinasyon imajını zedeleyerek turistlerin gözünde negatif algı oluşmasına yol açmaktadır. Öte yandan Parsons'a (1996) göre turizmde krizler ani, beklenen ve uzun süreli olmak üzere üç kategoride incelenmelidir. Buna göre Seymour ve Moore (2000) 
tarafından kobra tipi olarak adlandırılan ve meydana gelmeden önce neredeyse hiç uyarı sinyali vermeyen ani krizler, beklenmedik bir şekilde hızla gelişim göstererek, sorunun kaynağına inilmesine veya karşı önlemler almasına imkân tanımamaktadır. Piton tipi olarak tanımlanan muhtemel krizler ise daha yavaş hareket ederek adeta geleceğinin sinyallerini önceden vermektedir. Böylece olması beklenen piton tipi krizler önceden durdurulabilir veya olumsuz etkileri minimize edilebilir. Uzun süreli krizler ise haftalarca, aylarca hatta yıllarca devam ederek bu zorlu süreçte olumsuz yansımalarını turizm sektöründe gösterebilmektedir. Türkiye gibi turizm gelirleri ve turist sayıları yüksek olan ülkeler özellikle uzun süreli krizlerden etkilenirken, ülke turizmi ciddi niteliksel ve niceliksel kayıplar yaşamaktadır.

Turizm sektörü Richter'ın (1983) vurguladığı üzere güvenli seyahat ortamı ve olumlu diplomatik ilişkilerle paralellik göstererek büyümektedir. Enders ve diğerlerinin (1992) Avrupa kıtasında gerçekleștirdiği araştırmaya göre terör saldırıları sonrasında ülkeler önemli turizm kayıpları yaşamaktadırlar. Turizm sektörü açısından bakıldığında terör olayları gibi olumsuz gelişmelerin, turistlerin karar verme süreçlerini olumsuz yönde etkilediğini, rezervasyonların iptal edilmesine neden olduğunu, turistlerin tatil sürelerini kısalttığını, turistlerin tatil destinasyonu rotalarını değiștirmelerine veya tatillerini iptal etmelerine neden olduğunu ve etkilenen ülkelerin daha fazla turist çekebilmeleri için gereken harcamalarını artırdığı görülmektedir (Güzel vd., 2016). Türkiye'de son ylllarda adeta bir zincirin halkaları gibi birbirini takip eden krizleri tetikleyen terör saldırıları, göçmen hareketliliği, doğal afetler, siyasi anlaşmazlıklar, diplomatik ilişkilerdeki duraklamalar gibi birtakım olayların yaşanması nedeniyle ülkede ciddi anlamda olumsuzluklar baş göstermiștir. 2019 yılında Çin'in Hubei eyaletine bağlı Vuhan şehrindeki bir hayvan pazarında ortaya çıkarak 2020'de tüm dünyayı etkisi altına alan, kısa sürede aşırı yüklenilmesinden dolayı bir çok ülkede sağlık sistemlerinin çökmesine, sokağa çıkma yasaklarının getirilmesine ve binlerce insanın ölümüne neden olan "global ölçekli" yeni tip koronavirüs (COVID-19) hastalığı da bu olumsuz güncel gelişmeler arasındadır. Bu çalışmada, önemli turizm paydaşları arasında yer alan; icra ettikleri mesleğin doğası gereği turistlerle ve birçok turizm işletmesi ile yoğun iletişim ve etkileşim içinde olan turist rehberlerinin bakış açısıyla krizlerin ve olumsuz gelişmelerin turizm sektörüne yansımaları ve gerçekleştirilebilecek eylem planı girdileri kapsamlı olarak değerlendirilmiştir.

\section{Kuramsal Çerçeve: Krizlerin ve Olumsuz Gelişmelerin Türk Turizm Sektörüne Yansımaları}

Ülkelerin sosyo-ekonomik gelişme düzeyine, politik istikrarına ve dünya ekonomik konjonktüründeki olumsuz gelişmelere karşı duyarlı bir sektör olan turizm, ülkedeki yapısal ve konjonktürel sorunlardan çeșitli ölçülerde ve olumsuz biçimde etkilenmektedir (Ünlüönen vd., 2009, s.40). Turizmde krize neden olacak en önemli risk faktörleri terörizm, savaşlar, politik istikrarsızlık, salgın hastalık başta olmak üzere sağlık problemleri ve suçlar olarak sıralanmaktadır (Lepp ve Gibson, 2003). De Sausmarez'e (2007) göre krizler, insan (terörizm, diplomatik gerginlik, savaş vb.) ve doğa (tayfun, tsunami, deprem, kasırga, virüs salgını vb.) kaynaklı olmak üzere iki farklı şekilde ortaya çıkmaktadır. Turizm bağlamında tarihsel geçmiş incelendiğinde dünyadaki modern kitle turizm faaliyetlerini doğrudan etkileyen olumsuz gelişmelerin ardı ardına meydana geldiği ve ülkelerin turizm ekonomilerinde kısa sürede telafisi mümkün olmayan derin etkiler yarattığı görülmektedir. Körfez Savașı (1990); İkiz Kuleler Saldırısı (2001), Bali bombalı terör saldırıları (2002), Sars salgını (2002), Tsunami faciası (2004), Madrid Tren Garı saldırıları (2004), kuş gribi salgını (2005), Mısır Sharm-el-Sheik'te otele gerçekleştirilen bombalı saldırılar (2005), Katrina kasırgası (2005), Domuz gribi (2006), 
küresel ekonomik kriz (2008-2009), Arap Baharı (2011), Mers salgını (2012), Ebola salgını (2013), Mısır'da gerçekleşen darbe (2013), Paris terör saldırısı (2015), Brüksel'de bombalı saldırı (2016), Fransa'nın Nice kentinde bombalı araç saldırısı, Suriye olayları ve mülteci krizi (2015-2016-2020), Koronavirüs salgını (2019-2020) gibi olaylar dünya turizm hareketlerinde mevcut dengeleri sarsmıștır.

Hawaii Üniversitesi Ekonomi Profesörü Carl Bonham başkanlığında hazırlanan rapora göre, saldırılar neticesinde oluşan güvensiz atmosfer nedeniyle 2001-2004 yılları arasında $\mathrm{ABD}$, turizm gelirlerinde milyonlarca dolar kayıp vererek, turist sayısında 27 milyon kişiye ulaşan ani bir düşüş yaşamıştır (Sarıçay ve Ünal, 2014). Öte yandan Hint Okyanusu Depremi ve Tsunami sırasında en çok can kaybı yaşanan ülkelerden birisi Tayland'da turizm durma noktasına gelerek yüzlerce kişinin işsiz kalmasına zemin hazırlamıștır. 1990'larda baș gösteren Körfez Savașı ile kıvılcımlanan, Irak olayları, Arap Baharı, DEAŞ (IŞID) sorunu, İsrail-Filistin çekişmesi, Kudüs anlaşmazlığı, Suriye iç savaşı ve mülteci sorunuyla daha da alevlenen ve gergin iklimi körükleyen gelişmeler, Ortadoğu'da güven ortamını yok ederek bölgedeki turizm faaliyetlerine ağır darbe vurmuştur. Gerek sahip olduğu stratejik konum ile Avrupa ülkelerine geçiş noktası olması, gerekse siyasi veya toplumsal istikrar ve güvenlik sorunları yaşayan ülkelere olan coğrafi, dini ve kültürel yakınlığı nedeniyle Türkiye, belirli dönemlerde kriz ve olumsuz gelişmelerin etkilerine açık bir şekilde maruz kalabilmektedir. Yakın veya uzak coğrafyalardaki sosyo-ekonomik gelişmelerden, salgın tehlikelerinden, olumsuz diplomatik ilişkilerden, politik ve ekonomik krizlerden, savaşlardan, terörizmden, dünyanın önde gelen ülkelerinin kendi toprakları dışında uyguladığı siyasi veya tarihsel temelli faaliyetlerden veya uluslararası anlaşmazlıklardan hızlı etkilenen ve güncel gelişmelere hızlı tepki veren bir yapıda olan Türkiye'deki kitlesel turizm hareketleri, genellikle dış pazara ve yabancı tur operatörlerine bağımlı olarak domino etkisine açık; hassas dengeler üzerine kurulu bir mekanizma içinde faaliyet göstermektedir. Önemli tatil destinasyonları ile turistik çekim merkezlerine ev sahipliği yapan ve geçmişte turist sayılarını bir önceki yıla göre artırma eğiliminde olan Türkiye, özellikle son on iki yıl içinde meydana gelen olumsuz gelişmelerden önemli ölçüde etkilenmiştir. Özellikle 2020 yılında tüm dünya ile birlikte ülkeyi etkisi altına alan Çin kaynaklı koronavirüs salgını bașta olmak üzere meydana gelen olumsuz güncel gelişmeler ve diplomatik ilişkilerdeki anlaşmazlıklar neticesinde gün geçtikçe derinleşen ve etki çapını büyüten kriz ortamı, turizmde 'duraklama ve durgunluk dönemi' yaşanmasına neden olmuştur. Özellikle 2008 Ocak-2020 Nisan dönemi arasında Türkiye'de turizmi doğrudan veya dolaylı olarak etkilediği varsayılan gelişmeler değerlendirildiğinde Türkiye gündemini meşgul eden birçok olayın meydana geldiğini söylemek mümkündür. Bu gelişmeler: 'bombalı ve silahlı saldırılarla gerçekleştirilen terörizm, uluslararası arenada ortaya çıkan diplomatik krizler, turistlere yönelik saldırılar ve cinayetler, terör örgütlerine yönelik sınır ötesi askeri operasyonlar, 15 Temmuz darbe girişimi, mültecilerin Avrupa'ya geçişi için Türk sınır kapılarının açılması, düzensiz göçmen hareketliliği ve son olarak ülkemiz de dâhil olmak üzere tüm dünyayı etkileyen koronavirüs (COVID-19) salgını' olarak özetlenebilir. Bu gelişmeler neticesinde, tatilini Türkiye'de geçirmeye niyetli potansiyel ziyaretçilerin gözünde olumsuz bir destinasyon imajı oluştuğu, turizmde istikrarın büyük oranda sekteye uğradığı, uluslararası medyada turistlerin ülke içinde can güvenliğinin tehlikede olacağı algısının ortaya çıktığı; 'güven ortamı ve huzurlu tatil atmosferi' imajının zedelendiği söylenebilir. Özellikle "Türkiye'de turizm sektörü, gerek 2015 yılının sonlarında ve 2016 yılının ilk aylarında yaşanan terör eylemleri nedeniyle, gerekse muhtelif tarihlerde turistlere yönelmiş olan münferit olaylar nedeniyle, 2016 yılında zorlu bir döneme girmiştir. Türkiye'ye turist gönderen ülkelerdeki hükümetlerin ve medyaların olumsuz yaklaşımları da buna etki etmiştir" (Aras, 2017, s.589). 
2016 yılında gerçekleşen terör olaylarının en büyük kaybeden ülkelerinden biri olarak Türkiye'yi gösteren Isaac ve Velden (2018), Alman turistlerin Türkiye'ye yönelik tutumlarında seyahat risk algısı üzerine yaptığı çalışmada Almanların Türkiye güvenlik algısının oldukça düşük olduğunu ortaya koymuştur. Ayrıca araştırma katılımcıları, Türkiye ve Mısır'ı en güvensiz ülkeler olarak betimlerken, gelecek sene içinde Türkiye'ye seyahat etme isteklerinin oldukça düşük olduğunu belirtmiştir.

Tablo 1'de Türkiye Seyahat Acenteleri Birliği (TÜRSAB) ve Kültür ve Turizm Bakanlığı Yatırım ve İşletmeler Genel Müdürlüğü'den elde edilen veriler görülmektedir. Verilere göre Türkiye, 2008-2013 yılları arasında ziyaretçi sayısını ve turizm gelirini bir önceki yıla göre çok az miktarlarda artırmasına rağmen bu dönemde yavaş artış hızına sahip durağan karakterli bir grafik elde etmiștir. Tablo 1'de dikkati çeken bir diğer nokta, 2008-2009 yılları arasında dünyayı etkisi altına alan küresel ekonomik kriz yıllarında Türkiye'nin ziyaretçi sayısını ve gelirini ciddi oranda kayıp vermeksizin koruyabilmiş olmasıdır. Türkiye açısından olumsuz olayların ardı ardına patlak verdiği Suriye iç savaşı, mülteci krizi, darbe girișimi, terör olayları, Rus uçağının düşürülmesi ve Rus büyükelçi Andrey Karlov'un suikaste kurban gitmesi nedeniyle Rusya ile diplomatik ilişkilerin uzunca bir süre durağan ve gergin bir seyir izlemesi, AB ülkeleriyle diplomatik ilişkilerin sekteye uğradığı 2016 yılında Türkiye'nin bir önceki yıla göre 10 milyondan fazla ziyaretçi kaybına uğradığı görülmektedir. 2016 yılı Türkiye'nin maksimum düzeyde turizm geliri kaybına uğradığı dönem olarak göze çarpmaktadır. Veriler incelendiğinde 2016 yılında Türkiye'nin turizm geliri kaybının 9 milyon doları aştığı görülmektedir. Veriler, Türkiye'nin 2017 yılında turist sayısı ve gelir miktarını artırma eğiliminde olduğunu ve geçmişin izlerini silerek tekrar toparlanma sürecine girdiğinin sinyallerini vermektedir. Bunu doğrulayan 2018 ve 2019 verileri, turizm gelirlerinde önemli düzeyde bir artış kaydedildiğini göstermektedir. Ziyaretçi sayılarında yaşanan 2016'daki sert düşüşün 2017'de telafi edilerek sayının yukarı yönde ivme kazanması ve özellikle 2018 ile 2019 yıllarında yüksek rakamlara ulaşılması dikkat çekmektedir. Tüm dünya ile birlikte Türkiye'yi de etkisi altına alan ve turizmde duraklama dönemine neden olan COVID-19 salgınının şuan itibariyle netlik kazanmayan 2020 ziyaretçi rakamlarına nasıl yansıyacağı merak konusudur.

Tablo 1. 2008-2019 Dönemi Ziyaretçi Sayıları ve Turizm Gelirleri

\begin{tabular}{ccc}
\hline Yıl & Turizm Geliri (\$)* & Ziyaretçi Sayısı \\
\hline $\mathbf{2 0 0 8}$ & 19.612 .296 & 26.431 .124 \\
$\mathbf{2 0 0 9}$ & 19.063 .702 & 27.077 .114 \\
$\mathbf{2 0 1 0}$ & 19.110 .003 & 28.632 .204 \\
$\mathbf{2 0 1 1}$ & 22.222 .454 & 31.456 .076 \\
$\mathbf{2 0 1 2}$ & 22.410 .364 & 31.712 .832 \\
$\mathbf{2 0 1 3}$ & 25.322 .291 & 34.910 .098 \\
$\mathbf{2 0 1 4}$ & 27.778 .026 & 36.837 .900 \\
$\mathbf{2 0 1 5}$ & 25.438 .923 & 36.244 .632 \\
$\mathbf{2 0 1 6}$ & 15.991 .381 & 25.352 .213 \\
$\mathbf{2 0 1 7}$ & 20.222 .971 & 32.410 .034 \\
$\mathbf{2 0 1 8}$ & 24.028 .311 & 39.488 .401 \\
$\mathbf{2 0 1 9}$ & 28.704 .946 & 45.058 .286 \\
\hline
\end{tabular}

Kaynak: Kültür ve Turizm Bakanlığı (2019), TÜRSAB (2019). 
*Sadece ülkeye giriş yapan yabancı turist sayılarını ve onlardan elde edilen turizm gelirlerini kapsamaktadır. Yabancı ziyaretçilere ilişkin daha net bir analiz gerçekleştirmek amacıyla yurtdışında ikamet eden Türk vatandaşları kapsam dışında tutulmuştur.

Tablo 2'de Turizm Data Bank'tan elde edilen veriler ışığında 2013-2019 yılları arasında gerçekleșen paket tur satışları ve milliyetlere göre dağılımlarına yer verilmiștir. 2014 yılında toplamda 16 milyonu aşarak son beş yılın zirvesine ulaşan paket tur sayısı 2016 yılında sert bir düşüş yaşayarak 8,7 milyona gerilemiştir. Türkiye'de gerilimi tırmandıran olayların ve gündemi sürekli olarak değiștiren sıcak gelişmelerin yaşandığı 2016 yılının meydana getirdiği olumsuz iklimin bu ani düşüşte büyük payı olduğunu söylemek mümkündür. 2016 yılına damga vuran olayların başında turist gruplarına yönelik terör saldırıları, başkentte meydana gelen patlamalar, askeri darbe teşebbüsü, OHAL uygulaması, sınır ötesi operasyonlar, AB müzakerelerinde yaşanan duraksama ve yabancı devlet adamlarına yönelik suikastler gelmektedir. Birbiri ardına meydana gelen gelişmelerin sonucunda Türkiye karşıtı olumsuz imaj ve algının, paket tur satışlarında ani gerilemeye neden olduğu ve turizm faaliyetlerini olumsuz yönde etkilediği düşünülmektedir. En durgun dönemlere sahne olan ve krizin en yoğun olarak hissedildiği 2016 yllında Rusya'dan gelenlerde \%76,2, Avrupa ülkelerinden gelenlerde \%31 ve OECD ülkelerden gelenlerde \%35,9 oranında azalma meydana gelmiştir. 2016'da Rus turist sayısı 866 bin 256'da kalırken; Alman turist sayısı da \%30,3 oranında azalarak 3 milyon 890 bin 74 kişi olarak kaydedilmiştir (Doğruluk Payı Raporu, 2016). 2016'nın yaralarını sarmaya çalışan 2017 yılında paket tur satışları 11.4 milyona ulaşarak bir önceki yıla göre daha iyi bir grafik sergilemiștir. Bu yukarı yönde ki hareketin 2018 ve 2019 yıllarında ivme kazandığı ve paket tur satışlarının 2016 yılındaki kayıpları büyük ölçüde telafi ettiği görülmektedir.

2019 yılı sonlarında Çin'in Hubei eyaletine bağlı Vuhan kentinde ortaya çıkarak 2020 yılında Türkiye dâhil olmak üzere tüm dünyayı etkisi altına alan ölümcül koronavirüs salgının artması ve virüsün daha fazla yayılmaması için alınan seyahat yasakları, bu yükselen grafikte yeni bir duraklama dönemine girileceğinin sinyallerini vermektedir. Kültür ve Turizm Bakanlığı verilerine göre 2020 yılı Ocak-Şubat döneminde ülkemizi ziyaret eden yabancı sayısında 2019 yılının aynı dönemine göre \%9,68 artış kaydedilmiştir. Yeni tip koronavirus (Coronavirus/COVID-19) salgınına rağmen Şubat ayında Türkiye'yi ziyaret eden turist sayısı geçen yılın Şubat ayına göre yüzde 3.8 artarak 1 milyon 733 bine yükselmiştir. Bu geçici yükseliş seyri, 2020 Ocak-Şubat aylarında virüsün henüz dünyada tam yayılım göstermemiş olması, Türkiye'de ilk korona vakasının 10 Mart 2020 tarihinde görülmesi ve bununla birlikte virüsün etkilerinin Mart, Nisan ve Mayıs aylarında hissedilebileceği ile açıklanmaktadır. Uçak seferlerinin durma noktasına gelmesi ve salgın nedeniyle tedirgin olan ziyaretçilerin tatillerini ertelemeleri veya iptal etmeleri nedeniyle koronavirüsün 2020 turizmindeki asıl olumsuz etkisinin Mart ayından itibaren hissedileceği ve yaz ayı doluluk oranlarına olumsuz yansıyacağı tahmin edilmektedir. Salgının yayılış merkezi olan Çin bağlamında değerlendirildiğinde, 2020 Ocak-Şubat aylarında Türkiye'ye gelen Çinli turist sayısının geçtiğimiz senenin aynı dönemine göre yüzde 48 gerilediği görülmektedir (Kültür ve Turizm Bakanlığı, 2020). Türkiye'de 2020'ye ait toplam yıllık rakamlar, henüz netleşmese de Türkiye Otelciler Birliği (TUROB) tarafından açıllanan 2020 Mart ayı dış hat trafiğine ilişkin veriler, uçuşlarda \%15.7 oranında bir düşüş yaşandığını göstermektedir. 
İlker Șahin, F. Özlem Güzel, “Olumsuz Güncel Gelișmelerin ve Krizlerin Türk Turizmine Etkileri: Profesyonel Turist Rehberlerinin Değerlendirmeleri ve Sektörel Çözüm Önerileri”, İstanbul Gelişim Üniversitesi Sosyal Bilimler Dergisi, 7 (2), Ekim 2020, ss. 257-280.

Tablo 2. Paket Tur Satışları ve Milliyete Göre Dağılımı

\begin{tabular}{rrrrrrrrrr}
\hline & Toplam & Alman & Rus & İngiliz & Hollandalı & Ukraynalı & Íranlı & Fransız & Japon \\
\hline Yll & Milyon & Milyon & Milyon & Milyon & Bin & Bin & Bin & Bin & Bin \\
\hline $\mathbf{2 0 1 3}$ & 15,0 & 2,7 & 2,5 & 1,2 & 584,2 & 371,8 & 209,6 & 392,2 & 147,5 \\
$\mathbf{2 0 1 4}$ & 16,1 & 3,0 & 2,7 & 1,4 & 642,1 & 286,4 & 243,2 & 417,7 & 136,8 \\
$\mathbf{2 0 1 5}$ & 14,9 & 3,1 & 2,2 & 1,3 & 600,3 & 292,4 & 204,8 & 239,9 & 65,4 \\
$\mathbf{2 0 1 6}$ & 8,7 & 2,0 & 0,37 & 0,8 & 424,1 & 550,4 & 399,8 & 92,9 & 15,6 \\
$\mathbf{2 0 1 7}$ & 11,4 & 1,5 & 2,6 & 0,7 & 325,5 & 650,1 & 862,8 & 109,1 & 12,9 \\
$\mathbf{2 0 1 8}$ & 16,2 & 1,8 & 3,3 & 0,9 & 397,5 & 803,4 & 744,9 & 130,6 & 43,1 \\
$\mathbf{2 0 1 9}$ & 19,8 & 2,2 & 3,9 & 1,0 & 477,8 & 841,5 & 868,3 & 216,6 & 65,9 \\
\hline
\end{tabular}

Kaynak: Turizm Data Bank (2019).

Milliyete göre dağılım incelendiğinde uluslararası diplomatik ilişkilerde ve dış siyasette yaşanan gerilimler ve anlaşmazlıkların yarattığı olumsuzluk ikliminin paket tur satışları üzerinde etkili olduğu varsayılmaktadır. Tablo 2 incelendiğinde Almanların 2013-2015 yılları arasında yükselme eğiliminde olan paket tur alımlarının 2016 ve 2017 yıllarında kademeli olarak düşüş yaşadığı görülmektedir. Bu düşüşte 12 Ocak 2016 tarihinde Sultanahmet Meydanı'nda Alman turist gurubuna yapılan ve 12 ziyaretçinin ölümüyle sonuçlanan terör saldırısı ile 2017 Mart döneminde patlak veren ve karşılıklı sert siyasi söylemlerle alevlenen Türk-Alman ilişkilerindeki gerilimli dönemin önemli ölçüde payı olduğu düşünülmektedir. Öte yandan 24 Kasım 2015 tarihinde Rus Hava Kuvvetleri'ne ait Sukhoi Su-24M tipi uçağın sınır ihlali gerçekleştirmesinden dolayı düşürülmesi, Türk-Rus ilișkilerine büyük darbe vurarak gerilimin tırmanmasına neden olmuştur. Bu olayın ardından 2016 yılında Rusların Türkiye'ye yönelik paket tur alımları çok sert bir düşüş yaşayarak 2,2 milyondan 37 bine gerilemiş; iki ülke arasında turizm faaliyetleri durma noktasına gelmiştir. 2017 yılında Rusya ile diplomatik ilișkilerin yeniden kurulması ve eski seyrine geri dönmesiyle paket tur sayıları tekrardan yükseliş eğilimine girerek 2,6 milyon düzeyine ulaşmıştır. 2016 yılını diken üstünde geçiren turizm sektöründe gerileme yaşanmış; 2017 yılında patlak veren Türkiye-Hollanda Krizi ve Rotterdam Olayları iki ülke arasındaki diplomatik ilişkilerde gerginliğe yol açmıștır. Tablo 2 incelendiğinde Türkiye-Hollanda krizinin hüküm sürdüğü 2017 yılı diplomatik duraklama döneminde Hollandalı turistlerin paket tur alımlarında gözle görülür bir azalma meydana geldiği ve son beş yılın en alt seviyesine ulaşılarak rekor düzeyde düşüş yaşandığı dikkat çekmektedir. Tablo 2, 2018 ve 2019 yıllarında tüm milliyetler bazında yükselen paket tur satış grafiği elde edildiğini göstermektedir. Buna karşın koronavirüs salgının Türkiye'de ve dünyada henüz yeni ortaya çıkması ve bu salgının henüz netlik kazanmayan 2020 rakamlarına ne yönde yansıyacağının bilinmemektedir.

Tablo 3, önde gelen turizm paydaşlarının 2020 yılına ilișkin mevcut durum ve gelecek sezona yönelik genel değerlendirmeleri ve öngörülerinin ileriye dönük karamsar bir tablo çizdiğini göstermektedir. Tabloya göre Türkiye'nin farklı illerinde yaşayan turizm paydaşları, mevcut rezervasyon iptalleri ve ziyaretçi trafiğinin durma noktasına gelmesi nedeniyle turist sayısı bazında 2020 yılında bir önceki yıla göre gözle görünür bir düşüş yaşanacağını ve koronavirüsün olumsuz etkilerinin Nisan, Mayıs ve Haziran aylarında yoğun olarak hissedileceğini düşünmektedirler. 
Tablo 3. Paydaşların 2020 Sezonuna İlişkin Öngörü ve Değerlendirmeleri

\begin{tabular}{|c|c|c|}
\hline $\begin{array}{l}\text { Turizm } \\
\text { Paydașları }\end{array}$ & İl & Değerlendirme ve Öngörü \\
\hline Paydaş 1 & Van & $\begin{array}{l}\text { "Dünya genelinde turizmi vuruyor. Ciddi şekilde turizm } \\
\text { sıkıntıda. Etkisi şimdiden sonra görülecek. Rakamsal } \\
\text { veriler bizde mart - nisan ayından sonra çıkar. } 2020 \\
\text { sezonun çok iyi geçeceğini düsünmmüyorum. Talepler } \\
\text { bundan sonra düşecek. Ayrıca her yıl } 400 \text { bine yakın turist } \\
\text { ağırlayan Van'da bu yıl öncelikle mart ayında İran'dan } \\
\text { gelen } 200 \text { bin turistin gelmemesi kent esnafını kara kara } \\
\text { düșündürdü." }\end{array}$ \\
\hline Paydaş 2 & Konya & $\begin{array}{l}\text { "Konya'ya özellikle Çin, Güney Kore ve Iran'dan gelen } \\
\text { turist sayısı fazlaydı ancak coronavirus sebebi ile ve } \\
\text { uçuşların kapatılması nedeni ile yüzde yüz bir kayıp var. } \\
\text { Genel olarak ise Konya'ya gelen turist sayısında yüzde } 50 \\
\text { civarında bir azalma var. Coronavirus sebebi ile } \\
\text { acentaların yurtdıș organizasyonlarda da büyük bir kaybı } \\
\text { var. Íptaller acentaları etkiledi." }\end{array}$ \\
\hline Paydaş 3 & Kapadokya & $\begin{array}{l}\text { "Coronavirus, Kapadokya Bölgesi'ni birkaç yıl önceki kriz } \\
\text { günlerine geri götürdü. Kapadokya'nın haziran sonuna } \\
\text { kadar yüzde } 60 \text { ila } 70 \text { 'e varan kaybı var. Eğer bu panik } \\
\text { havası devam ederse yılın ikinci kısmını da kaybederiz. } \\
\text { Basında oluşan panik havası nedeniyle yerli turisti de } \\
\text { kaybettik” }\end{array}$ \\
\hline Paydaş 4 & Antalya & $\begin{array}{l}\text { "Dışişleri Bakanlığı tarafından bu yıl mayıs ayında ilki } \\
\text { yapılması planlanan devlet ve hükümet başkanları ile } \\
\text { dünyanın tanıdığı isimlerin yer alacağı Antalya Forumu da } \\
\text { iptal edildi. Rezervasyonlarda az da olsa iptaller } \\
\text { yașanıyor. Rusya Tur Operatörleri Birliği, Türkiye'ye talep } \\
\text { olduğunu ancak yüzde } 25 \text { düşüs görüldüğü bilgisini verdi. } \\
\text { Avrupa pazarında satışlarda ise ciddi düșüssler var." }\end{array}$ \\
\hline
\end{tabular}

Not: Röportajlarda verilen demeçler, 16 Mart 2020 tarihli Turizm Günlüğü Turizm ve Seyahat Gazetesi'nden derlenmiştir (https://www.turizmgunlugu.com/2020/03/16/coronavirusturkiyenin-turistik-noktalarina-etkisi/).

\section{Yöntem}

Araştırma kapsamında veriler, ölçüt örnekleme yöntemi kullanılarak en az bir yıllık deneyime sahip turist rehberlerinden yüz yüze ve eş zamansız görüşme metoduyla toplanmıştır. Turist rehberlerinin bakış açısıyla Türkiye'de yaşanan olumsuz gelişmelerin ve krizlerin turizm sektörü üzerinde ortaya çıkardığı olumsuz etkileri en aza indirmek için neler yapılması gerektiğinin betimsel yaklaşımla ele alınması; farklı meslek odalarına kayıtlı olarak bir veya birden fazla turizm destinasyonunda farklı dillerde görev yapan rehberlerden veri toplanması nedeniyle araștırma bütüncül çoklu desende kurgulanmış tipik bir durum çalışması niteliğindedir. Betimsel analiz, verilerin daha önceden belirlenmiş temalara göre özetlenerek yorumlanmasını içeren bir nitel veri analiz türüdür. Araştırmacı görüşmecilerin düşüncelerini çarpıcı bir biçimde yansıtabilmek için doğrudan alıntılara sık sik yer verebilmektedir. Temel amacı ise elde edilmiş olan bulguların okuyucuya özetlenmiş ve yorumlanmış bir şekilde net bir biçimde 
İlker Şahin, F. Özlem Güzel, “Olumsuz Güncel Gelișmelerin ve Krizlerin Türk Turizmine Etkileri: Profesyonel Turist Rehberlerinin Değerlendirmeleri ve Sektörel Çözüm Önerileri”, İstanbul Gelişim Üniversitesi Sosyal Bilimler Dergisi, 7 (2), Ekim 2020, ss. 257-280.

sunulmasıdır (Yıldırım ve Şimşek, 2003). Nitel araștırma yöntemini temel alan bu çalışma kapsamında; yüz yüze görüşme ve e-mülakat olmak üzere iki aşamalı veri toplama tekniğinden yararlanılarak toplamda 65 rehberden veri toplanmıştır. Bu amaçla veri toplama sürecinin ilk aşaması olarak aktif çalışan 5 turist rehberi ile kendilerinin tercih ettiği turistik merkezlerde yüz yüze görüşmeler gerçekleştirilmiştir. Akademik etik kuralları ve nitel araştırma yönteminin bir gereği olarak görüşmeyi kabul eden ve bilgi vermek isteyen rehberlerden imzalı izin formları toplanarak anlık ses kayıtları alınmıştır. Biri Antalya, dördü ise İstanbul'da olmak üzere toplam 5 rehber ile ortalama bir buçuk saat süren yüz yüze görüşmeler gerçekleștirilmiştir. Tüm görüşmelerin belirli bir ölçüde tutarlılık içerisinde olması ve "ülkede var olan güncel gelişmeler ve krizler" olgusuna ilişkin başlıca konuları tespit etmek amacıyla yarı yapılandırılmış soru formları kullanılmıștır. Soru formunda demografik özelliklerin belirlenmesine ilişsin soruların yanı sıra güncel gelişmeler ve krizlere yönelik katılımcıların deneyimlerine ve görüşlerine bağlı olarak katılımcılarına șu sorular yönetilmiștir;

S1. Türkiye'de son 10 yılda meydana gelen gelişmeleri ve krizleri dikkate alarak, turizm sektöründe ortaya çıkan yapısal özellikleri değerlendirir misiniz?

S2.Genel olarak turizm sektöründe ortaya çıkan bu yapısal özeliklere ilişkin neler yapılabilir? Kamuya ve sektöre yönelik çözüm önerileriniz nelerdir?

Veri toplama sürecinin ikinci aşamasında ise e-posta yöntemiyle görüşme (emülakat) tekniğinden yararlanılmıştır. Bu yöntemle veriyi çeşitlendirmek; konuya ilişkin daha detaylı ve daha nitelikli bulgular elde ederek derinlemesine bilgiye ulaşmak amaçlanmıştır. Eş zamansız görüşme yöntemin izlenmesinin bir diğer nedeni ise rehberlerin coğrafi olarak birbirinden farklı yerlerde ikamet etmeleri, mesleğin doğası gereği sürekli seyahat halinde olmalarıdır. E-posta mülakatları eş zamanlı (synchronous) ve eş zamansız (asynchronous) olmak üzere iki kategoriye ayrılmaktadır. Birinci teknikte araştırmacı ve katılımcı çevrimiçi yazışma (chat/sohbet) programı kullanarak anlık görüşme gerçekleștirilebilmektedir. Eş zamansız teknikte ise gönüllülük esasına dayalı olarak katılımcılar belirlenmekte ve e-posta mesajı gönderilerek, katılımcılardan görüşme formundaki soruları yanıtlamaları istenmektedir. E-posta mülakat metoduna, katılımcılarla yüz yüze görüşmenin mevcut şartlar dâhilinde mümkün olmadığı veya çok kısıtlı olduğu durumlarda ya da katılımcıların birbirinden uzak ve farklı coğrafyalarda bulunması hallinde başvurulmaktadır. Ayrıca e-mülakatlar, katılımcının sorular hakkında düşünmek için zamana ihtiyaç duyduğu durumlarda ya da çalışmayı zorlaştırıcı zamansal, mekânsal ya da maddi kısıtların mevcut olması halinde kullanılmaktadır (Shieffield University, 2012; Hewson, 2010, Mann ve Stewart, 2003). Bu bilgilerden yola çıkılarak 'eş zamansız e-mülakat tekniği' kullanılarak rehberlere e-posta, telefon ve çevrimiçi iletişim araçları yardımıyla yüz yüze görüşmelerde kullanılan soru formları gönderilmiştir. Böylelikle yüz yüze görüşmelere ek olarak araştırmaya gönüllü katılım gösteren 60 turist rehberinden e-mülakat yoluyla veri toplanmıștır. Özel bilgileri koruma altına almak amacıyla e-posta ile ulașılan katılımcı rehberler K1-K60 arasında değișen sayılar kullanılarak; yüz yüze görüşme gerçekleștirilen rehberler ise ' $K T 1, K T 2, K T 3$, KT4 ve KT5' olarak kodlanmıştır. İki etaptan oluşan veri toplama sürecinin sonunda elde edilen rehber görüşleri, betimsel analiz yöntemi kullanılarak detaylı olarak çözümlenmiştir. Çalışmanın iç geçerliliğinin sağlanması için katılımcılara izin formu imzalatılmış, dış geçerlilik için araştırma süreci katılımcılara ayrıntılı bir şekilde açıklanarak amaçlı örneklem yöntemiyle gönüllülük esasına dayalı olarak katılımcılar ile görüşmeler yapılmıştır. Görüşmelerden elde edilen veriler kodlama yoluyla tasnif edilmiş ve temalandırılmıştır. Bu noktada, Yüksel ve Yüksel (2004) nitel çalışmalarda veri seti kodlama benzerliklerinin sayısal ve tematik olarak karşılaștırılmasını önermekte; aradaki benzerliğin \%70 ve üzeri 
bir yüzdeye ulaşılması halinde güvenirliğin elde edilebileceğini belirtmektedir. Çalışmanın dış güvenirliliğini sağlamak amacıyla araştırma bulguları kapsamında elde edilen temalar ve alt temalar uzman görüşüne sunularak geçerli yüzdelik (\%70) elde edildikten sonra bulgular, katılımcıların bireysel bakış açılarını yansıtan özgün bir format kullanılarak detaylı olarak raporlanmıştır.

\section{Bulgular}

Tablo 4'te çalışmaya katılan rehberlere ilişsin demografik bilgiler yer almaktadır. Tablo incelendiğinde araştırmada yer alan katılımcıların çoğunlukla erkek (n:56), yüksek mesleki deneyime sahip rehberlerden oluștuğu dikkat çekmektedir. Bununla birlikte 3649 yaş aralığındaki rehberlerin çalışmaya daha fazla ilgi gösterdikleri; İngilizce, Almanca ve Fransızca dillerinde rehberlik çalışma kartına sahip oldukları görülmektedir.

\begin{tabular}{cccc}
\multicolumn{4}{c}{ Tablo 4. Katılımcıların Demografik Profili } \\
\hline Cinsiyet & $\mathbf{n}$ & Diller & n \\
\hline Erkek & 55 & İngilizce & 45 \\
Kadın & 10 & Almanca & 14 \\
Yaș Grubu & $\mathbf{n}$ & Fransızca & 13 \\
\cline { 1 - 1 } 26-35 Arası & 19 & Diğer Diller & 18 \\
36-49 Arası & 25 & Mesleki Deneyim & $\mathbf{n}$ \\
50-65 Arası & 18 & 1-24 Yll & 45 \\
66-79 Arası & 3 & 25-50 Yıl & 20 \\
\hline
\end{tabular}

Katılımcıların demografik özelliklerinin değerlendirilmesi sonrasında betimsel analiz gerçekleştirilmiştir. İfadelerin çözümlenmesi esnasında turizm aktörleri olarak rehberlerin seçiminin ne denli doğru bir yaklaşım olduğunu bir katılımcının belirttiği "hem ulusal ve dış medyayı takip ettiğimiz hem de bizimle tur yapmıș misafirlerimizle hala iletişimde olduğumuz için Türkiye'ye yönelik oluşan algıyı politikacılardan çok daha yakından takip ediyoruz." (K4) ifadesi doğrulamaktadır. Yaplan betimsel analiz sonucunda turist rehberlerinin "Türkiye'de son 10 yılda meydana gelen olumsuz gelişmeleri ve krizleri dikkate alarak, turizm sektörü hakkında genel bir değerlendirme yapar mısınız?" sorusuna yönelik olarak turizme ilişkin görüşlerinin çözümlenmesiyle elde edilen tematik bulgular Şekil 1 ve Tablo 5'de yer almaktadır. Katılımcılara, yönlendirilen soruda "belirlenen tarih aralığında meydana gelen olumsuz gelişmeler ve krizler" ibaresi, çalışmanın amacına uygun olarak katılımcılarda bilişsel bir sınırlılık getirmiș olup, betimleme analizinde verilen cevapların bu yönde ilerlediğini göstermektedir. Tablo 5 'de görüldügü üzere turizmin yapısına ilișkin 4 temel tema elde edilmiştir. 65 turist rehberi tarafından söz konusu soruya verilen yanitlar birbiriyle büyük oranda benzerlik gösterdiğinden, Tablo 5 'de yalnızca yüz yüze görüşme yapılan 5 rehberden alınan örnek alıntılara yer verilmiştir. Bu temalar, içerdikleri alıntılar bağlamında araştırmacılar tarafından "kırılgan yapı, rekabetçi yapı, ikame edilebilirlik ve ülke imajı etkin” olarak isimlendirilmiştir. Bu temalar bir bütün olarak, Türkiye'de son yıllarda yaşanan güncel olayların turizmin olumsuz yönlerinin nasıl ortaya çıkabileceğini de gözler önüne sermiştir. 


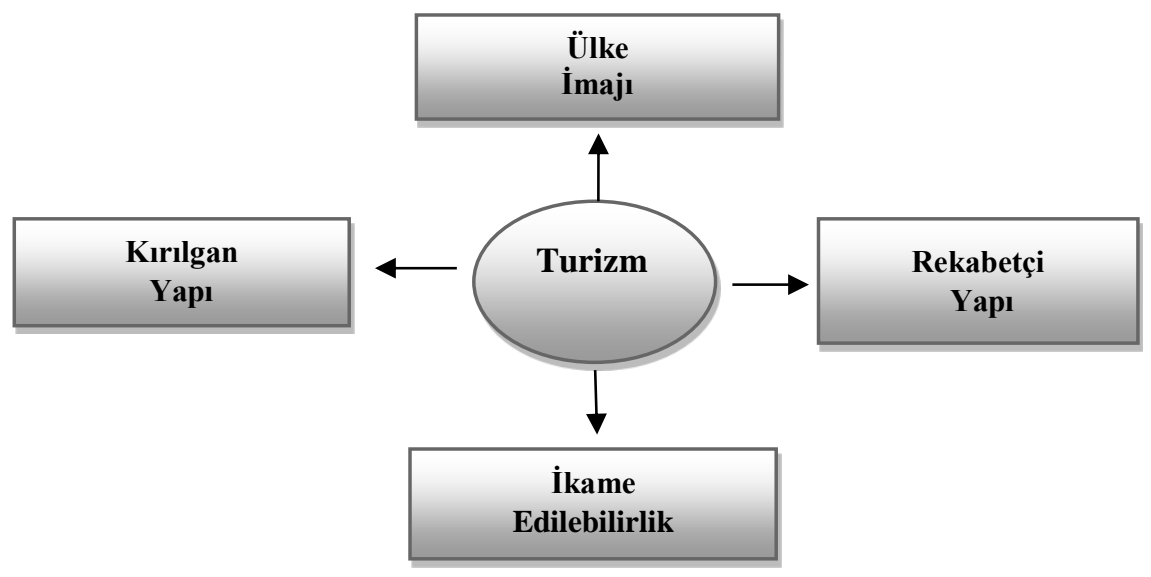

Şekil 1. Betimsel Çözümleme Sonucunda Elde Edilen Temalar

Tablo 5'de söz konusu birinci soruya verilen cevaplara yönelik betimsel çözümlemeye ilişkin, temalar, alt temalar ve alıntılar görülmektedir. Kırılgan yapı teması, turizmin hassas bir sektör olduğunu, savaş ve terör gibi olaylardan anında etkilendiğini ve aynı zamanda ülke içinde sosyal huzursuzluğun olmasının bir dezavantaj olduğunu ortaya koymaktadır. Turizmin rekabetçi bir yapıya sahip olduğu da ikinci tema olarak ortaya çıkmıştır. Turizm sektörünün içinde birbirinden bağımsız ünitelerin var olması, kapitalist ekonomik kuralların geçerli olması, destinasyonlar arasında sınırların olmaması ve dolayısıyla rekabetin yoğun olması unsurları bu temanın içeriğini oluşturmaktadır. Bu bağlamda ülkede gerçekleşen olumsuz gelişmeler nedeniyle ülke turizm rakamlarında doğrudan ve dolaylı olarak kayıplar yaşamaktadır. Üçüncü tema ülke imajı etkinliği olarak isimlendirilmiştir. Bu tema altında katılımcılar ülkede huzur ve güven ortamının olması gerektiğini aksi takdirde turistin gelmeyeceğini vurgulamışlardır. Son yıllarda yaşanan ve turistlerde risk algısı oluşturan gelişmeler, destinasyonlarda güvenli ortamın önemini bir kez daha ortaya koymuştur. Son tema olarak ise turistik ürünlerin ikame edilebilirliği ortaya çıkmıştır. Turistlerin her hangi bir olumsuzlukta tatillerinden vazgeçebilecekleri vurgulanmıștır. 
Tablo 5. Turizmin Yapısal Özelliklerine İlişkin Betimsel Çözümleme

\begin{tabular}{|c|c|c|}
\hline Tema & Alt Tema & AlintI \\
\hline $\begin{array}{l}\text { Kırılgan } \\
\text { Yapı }\end{array}$ & $\begin{array}{l}\text {-Hassas } \\
\text { Sektör } \\
\text { - Savaş } \\
\text { - Terör } \\
\text { - Sosyal } \\
\text { Huzur }\end{array}$ & $\begin{array}{l}\text { "Turizm çok hassas bir sektör olduğu için en ufak olumsuz bir } \\
\text { olayda mutlaka negatif olarak etkileniyor. Turistlere hizmetleri } \\
\text { huzur içerisinde rahatllkla alabilecekleri herhangi bir riske } \\
\text { girmeden alabilecekleri bir ortam sunmak gerekiyor." (KT1, } \\
\text { KT5) } \\
\text { "Bir ülkeye giden turist gitmeden en önce hayat garantisiyle } \\
\text { gider. Son dönemdeki olaylar yüzünden Türkiye'ye gelemediği } \\
\text { için turistler, Yunanistan'a ya da Balkan ülkelerine gidiyorlar." } \\
\text { (KT2) }\end{array}$ \\
\hline $\begin{array}{l}\text { Rekabetçi } \\
\text { Yapı }\end{array}$ & $\begin{array}{l}\text {-Kapitalist } \\
\text { Ekonomik } \\
\text { Kurallar } \\
\text {-Bağımsız } \\
\text { Ünitelerin } \\
\text { Varlığı } \\
\text {-Sınırsızlık } \\
\text {-Rekabet } \\
\text { Yoğunluğu }\end{array}$ & $\begin{array}{l}\text { "Turizm hizmetleri özellikle de konaklama, dinlenme sektörü } \\
\text { olarak Dünya üzerinde gerçek anlamda kapitalist ekonomik } \\
\text { kuralların uygulandığı küçük bilimlerden oluşan ürün tarzıdır. } \\
\text { Turizm rekabetçiliğin en yoğun olduğu sektördür. " (KT1) } \\
\text { "Turizm denildiğinde dünya üzerinde sınır tanımayan en } \\
\text { rekabetçi sektörden söz ediyoruz. Son dönemdeki olaylar } \\
\text { yüzünden Türkiye'ye gelemediği için turistler, Yunanistan'a ya } \\
\text { da Balkan ülkelerine gidiyorlar. (KT2) }\end{array}$ \\
\hline $\begin{array}{l}\text { Ülke } \\
\text { İmajı }\end{array}$ & $\begin{array}{l}\text { - Huzurlu } \\
\text { Ortam } \\
\text { - Güvenli } \\
\text { Ortam }\end{array}$ & $\begin{array}{l}\text { "Tatil, turistin çok kolaylıkla vazgeçebileceği bir üründür. Bu } \\
\text { ürünü bir defa huzurlu ve güvenli olduğ y yani rahatça } \\
\text { tüketebileceği bir ortamda tüketmeyi tercih eder." (KT1) } \\
\text { "Turizmin ülkemizde çok iyi olabilmesi ülkedeki güven } \\
\text { ortamına bağlı. Terör olsa bile dışarıya yansıttığı güvene bağll." } \\
\text { (KT3) }\end{array}$ \\
\hline $\begin{array}{l}\text { İkame } \\
\text { Edilebilirlik }\end{array}$ & $\begin{array}{l}\text { - Vazgeçile- } \\
\text { bilir Ürün } \\
\text { - Temel } \\
\text { İhtiyaç } \\
\text { Olmaması }\end{array}$ & $\begin{array}{l}\text { "Tatil ihtiyacl, turistin her ne olursa olsun karşılamak zorunda } \\
\text { olduğu bir ihtiyaç değil. Çok kolayllkla vazgeçebileceği bir } \\
\text { üründür. Temel ihtiyaç olmadığı için bunu elde etmek için } \\
\text { zorlamasına gerek yoktur." (KT1) } \\
\text { "Insanların başına bir şey geldiğinde ilk vazgeçeceğiniz şey } \\
\text { yemek değil gezmektir. Turizm ilk başta hemen etkilenecek } \\
\text { olandır." (KT4, KT5) }\end{array}$ \\
\hline
\end{tabular}

Betimsel analiz sonucunda ortaya çıkan önerilere ilişkin temalar Şekil 2 ve doğrudan alıntıları içeren genel bulgular ise Tablo 6'da gösterilmiştir. Temalar, "turizm politikalarında yapılanma, politik ilişkilerin kurulması, düzenleyici önlemlerin alınması, arz yapılanması, turizm bilincinin artırılması ve eğitim, kültür turizmine teşvik, alternatif turizm ve sürdürülebilirlik, turistik ürün oluşturma ve pazarlama, tanıtım faaliyetleri, hedef pazar çalışmaları, destinasyon markalaşması, etkinlik planlama, güvenlik vaadi, finansal destek" olarak isimlendirilmiștir. Temaların bu denli yoğun olması, özellikle olumsuz gelişmelere yönelik olarak turizm adına yapılabilecek çok sayıda eylemin varlığına işaret etmektedir. Tablo 6'da görüldüğü üzere güvenlik vaadinin sağlanması ana teması araştırmanın amacı bağlamında ortaya çıkan önemli bulgular arasında yer almıştır. Bu bağlamda katılımcılar, güvenlik çemberinin genişletilmesi gerektiğine, böylece turistik mekânların güvenliğinin sağlanabileceğine, terörün önlenebileceğine, güven ortamının oluşturulmasına ve sosyal huzurun sağlanmasına dikkat çekmişlerdir. Rehberlerin turizm işletmeleri çalışanlarını göz önüne alarak verdikleri yanıtlar doğrultusunda finansal destek teması ortaya çıkmıştır. Ülkede yaşanan olumsuz gelişmelerden turizmin etkilendiği dönemlerde devletten beklentiler vergi affı, faizsiz kredi imkânı ve tur ücretlerinde indirim olarak ortaya çıkmıștır. Türkiye'de son ylllarda yaşanan güncel gelişmelere yönelik olarak ortaya çıkan temalar değerlendirildiğinde, turizm politikalarında yapılanmanın politika revizyonu, turizm stratejilerinin planlanması, aktif turizm komitelerinin oluşturulması ve yatırım teşviklerinin turist ve gelir kapasitesi dâhilinde sorgulanması içeriklerini kapsadığı görülmektedir. Politik ilişkilerin ise turizm 
üzerindeki önemini vurgulayan temaya göre uzlaşmacı diplomatik ilişkilerin ve olumlu siyasi ilişkilerin kurulmasının gerekliliği ortaya çıkmıştır. Düzenleyici önlemlerin alınması teması oldukça zengin bir içerikle oluşurken, gerek turistleri gerekse çalışanları korumaya yönelik eylemlerin gerçekleştirilmesi konuları ortaya çıkmıștır. Bu bağlamda turisti koruyan yasal önlemlerin artırılması, turistlere ilişkin müzmin sorunların çözülmesi, turizm operatörlerinin kontrolü, kalifiye çalışanların korunması, etkin turizm yöneticilerinin atanması ve komisyonların denetimi/faturalandırılması alt temaları öneri olarak sunulmuştur. Arz yapılandırılması kapsamında, paydaş olarak rehberler hem kriz dönemleri dışında hem de kriz dönemlerinde Türkiye turizm sistemindeki aksaklıkların düzeltilmesine yönelik önlemlerden söz etmişlerdir. Bu kapsamda otel standartlarının gözden geçirilmesi, sigorta sistemi kurulması, her şey dâhil sisteminin kaldırılması, tur kalite standartlarının yükseltilmesi, hızla dijital pazarlama ve programlamaya geçilmesi, acentelerin kamulaştırılması ve yerli tur operatörlerinin kurulması konularının önem kazandığı görülmektedir. Yine benzer şekilde hem kriz dönemlerinin dışında hem de kriz dönemlerinde turizm bilincinin artırılması ve eğitim teması içinde yerel halkın bilinçlendirilmesi ile mesleki, iş ahlakı ve uzmanlaşma eğitimlerinin planlanması başlıkları ortaya çıkmıştır. Kültür turizminin teşvik edilmesi ortaya çıkan diğer bir önemli temadır. Bu tema içerisinde kültür turizminin teşvik edilmesi, kültürün ürün olarak sunulması, kültürel Anadolu turlarının tasarımı, uygun fiyatlı kültürel paket turların tasarımı ve bu bağlamda acentelere ören yeri girişi desteği verilmesi gerektiği vurgulanmıştır. Alternatif turizm ve sürdürülebilirlik teması güncel olumsuz gelişmeler karşısında turizmi destekleyici bir öneri olarak sunulmuş olup, ayrı bir boyutta temalandırılmıştır. Bu bağlamda alternatif turizm türlerinin tespit edilmesi, alternatif turizm türlerinin desteklenmesi, doğa, yat, kongre, etkinlik ve golf turizm türleri için avantajların kullanılması önerilirken, sürdürülebilir turizm yönetimine de vurgu yapılmıştır.

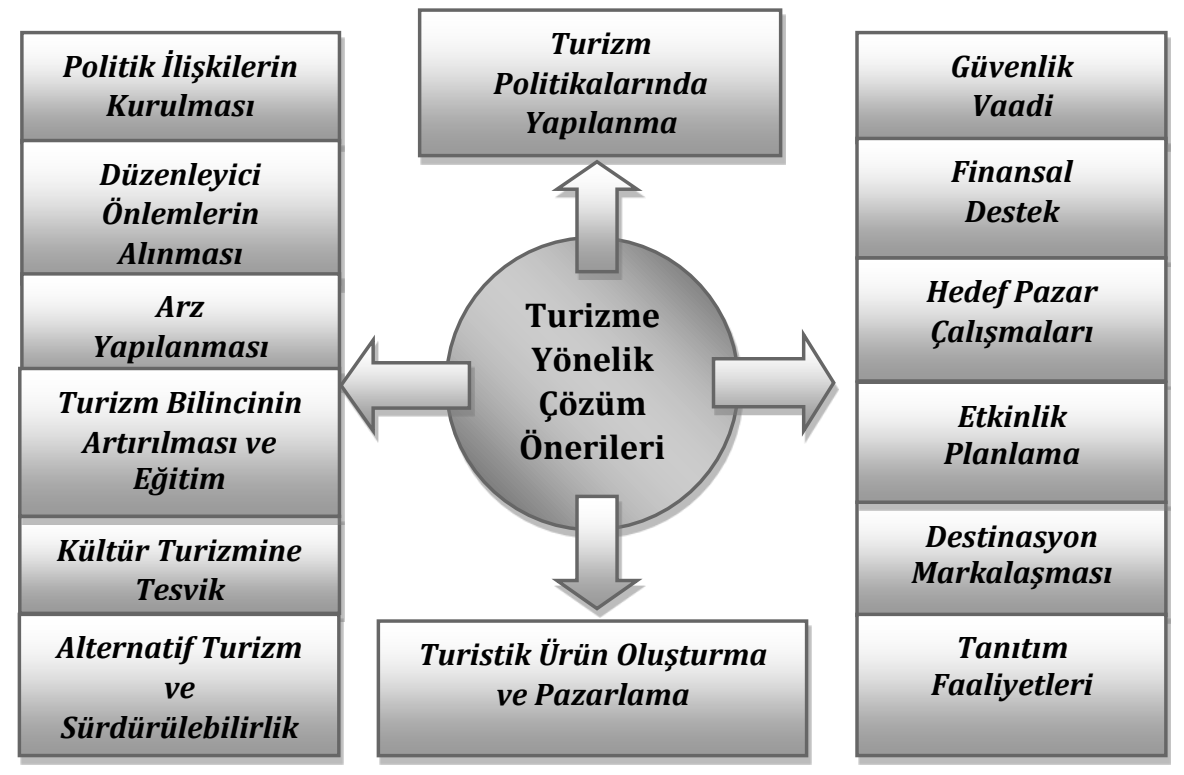

Şekil 2. Turizm Sektörüne Yönelik Çözüm Önerilerine İlișkin Temalar 
İlker Şahin, F. Özlem Güzel, “Olumsuz Güncel Gelișmelerin ve Krizlerin Türk Turizmine Etkileri: Profesyonel Turist Rehberlerinin Değerlendirmeleri ve Sektörel Çözüm Önerileri”, İstanbul Gelişim Üniversitesi Sosyal Bilimler

Dergisi, 7 (2), Ekim 2020, ss. 257-280.

Turistik ürün oluşturması ve ürünün pazarlaması konusu ise önemli bulgular sunan bir diğer temadır. Katılımcılar uzak mesafeli ülkeler için ürün geliştirilmesini ve kombine turların planlanmasını önerirken, ikili uçuş anlaşmaları ile desteklenerek destinasyon alternatiflerinin çoğaltılmasına vurgu yapmışlardır. Tanıtım faaliyetleri teması en çok vurgu yapılan ve öne çıkan tema olmuştur. Ülke tanıtımı konusunda yetersiz kalınan noktalara dikkat çeken katılımcılar güncel gelişmeler karşısında olumlu imaj yaratan faaliyetlerin gerçekleştirilmesinde fayda görmektedirler. Bu bağlamda tanıtım ekiplerinin oluşturulması gerektiğini, dil bildikleri için rehberlerin tanıtımda aktif olarak kullanılabileceğini, lobicilik faaliyetlerinin gerçekleștirilmesi, yurtdışı medyası ile etkin iletişim kurulması gerektiğini, film sponsorluklarının alınması ve sosyal medyanın aktif şekilde kullanılması gerektiğini, tüm bunların bireysel tanıtım faaliyetleriyle de desteklenmesi gerektiğinin altını çizmişlerdir.

Tablo 6. Turizme Yönelik Çözüm Önerileri

\begin{tabular}{|c|c|c|}
\hline Tema & Alt Tema & Alıntı \\
\hline $\begin{array}{l}\text { Güvenlik } \\
\text { Vaadi }\end{array}$ & $\begin{array}{l}\text {-Güvenlik Cemberini } \\
\text { Genişletme Vaadi } \\
\text {-Turistik mekânların } \\
\text { Güvenliğini Sağlama } \\
\text {-Sürdürülebilir Barıș ve } \\
\text { Huzur Ortamı Yaratma } \\
\text {-Terörizmin Önlenmesi } \\
\text {-Ülke İçinde Güven } \\
\text { Ortamının Yaratılması } \\
\text {-Sosyal Huzurun } \\
\text { Sağlanması }\end{array}$ & $\begin{array}{l}\text { "En son Yeni Zelanda ve Avustralya kendi vatandaşlarına } \\
\text { terörizmden dolayı gitmeme uyarısı yaptı. Yetkililerin her } \\
\text { gelen vatandaşından ben sorumluyum, olağanüstü güvenlik } \\
\text { önlemleri alıoruz vs. gibi açıklamalar yapılmalıdır." (KT3) } \\
\text { "Vatikan'l, Paris'i güvenlik sağlama konusunda görmek lazım. } \\
\text { Polis kontrolü, turnike sistemi yapılabilir." (KT5) } \\
\text { "Sakinlik, huzur, barıș ortamı sağlanmall." (K19) } \\
\text { "Siyasiler acilen ve ciddi olarak Türkiye'nin güvenilir ülke } \\
\text { olduğunu her firsatta dile getirmeli ve yabancılara } \\
\text { güvenilirliği hissettirmek için gerekli düzenlemeleri } \\
\text { yapmalıdır." (K32) } \\
\text { "SıIırlarımızdaki ülkelerle sürdürülebilir barış ortamını } \\
\text { sağlamalıyız." (K12) }\end{array}$ \\
\hline $\begin{array}{l}\text { Turizm } \\
\text { Politikalarında } \\
\text { Yapılanma }\end{array}$ & $\begin{array}{l}\text {-Politika Revizyonu } \\
\text {-Turizm Stratejilerinin } \\
\text { Planlanması } \\
\text {-Turizm Komitelerinin } \\
\text { Oluşturulması } \\
\text {-Yatırım Teşviklerinin } \\
\text { Sorgulanması }\end{array}$ & $\begin{array}{l}\text { "İyi bir planlama yapılarak turizm stratejileri tespit } \\
\text { edilmelidir. Her kesimin davet edildiği toplantılar yapılmall, } \\
\text { komiteler kurulmalı, strateji tespit edilmeli ve tanitım ekipleri } \\
\text { kurulmalıdır. Turizm teşviklerine son verilmeli. Kaliteyi artırıp } \\
\text { fiyatları yükseltecek ve turizm gelirini yükseltecek politikalar } \\
\text { gerekir." (KT1) } \\
\text { "İspanya, İtalya gibi turizm politikamızın olması gerekir." } \\
\text { (K12) }\end{array}$ \\
\hline $\begin{array}{l}\text { Politik İlişkilerin } \\
\text { Kurulması }\end{array}$ & $\begin{array}{l}\text {-Uzlaşmacı Diplomatik } \\
\text { İlişkiler } \\
\text {-Olumlu Siyasi İlişskiler }\end{array}$ & $\begin{array}{l}\text { "Diplomatik anlamda mümkün mertebe her ülke ile uzlaşmacı } \\
\text { karşılıklı çıar ve ilişkilere dayalı ülke menfaatine yönelik } \\
\text { olumlu politikalar izlenmelidir." (K47) } \\
\text { "Yapılması gereken ilk şey devlet politikası olarak yabancı } \\
\text { ülkelerle maksimum düzeyde iyi ilişskiler içerisinde olmaktır." } \\
\text { (K59) }\end{array}$ \\
\hline $\begin{array}{l}\text { Düzenleyici } \\
\text { Önlemlerin } \\
\text { Alınması }\end{array}$ & $\begin{array}{l}\text {-Turisti Koruyan Yasal } \\
\text { Önlemlerin Artırılması } \\
\text {-Turistlere İlişkin Müzmin } \\
\text { Sorunların Çözülmesi } \\
\text {-Tur Operatörlerinin } \\
\text { Kontrolü } \\
\text {-Kalifiye Çalışanların } \\
\text { Korunması } \\
\text {-Etkin Turizm } \\
\text { Yöneticilerinin Atanması } \\
\text {-Komisyonların } \\
\text { Denetimi/Faturalandırma }\end{array}$ & $\begin{array}{l}\text { "Artı yan gelirlerle para kazanma ortadan kaldırılmalı. Her } \\
\text { șey kanunlar çerçevesinde yapılmalı. Kaçak iş̧̧ilik dahil } \\
\text { faturasız gelir dahil her şey kanunlar çerçevesinde } \\
\text { yapılmalıdır." (K1) } \\
\text { "Turistleri koruyacak emniyetin ve denetimlerin artması } \\
\text { lazım. " (K5) } \\
\text { "Ülke vatandașı olmayanlara acente ve rehberlik faaliyetleri } \\
\text { yaptırmamalıdır." (K22) } \\
\text { "Turizmi, turizmin içinden gelen vizyon ve misyon sahibi } \\
\text { kişilerin yönetmesi gerekmektedir. Yabancıların izinsiz olarak } \\
\text { ülke içinde çalıșmaları yasaklanmall, is istihdam alanlarına } \\
\text { turizm eğitimi almış kişilerin getirilmeleri gerekmektedir." } \\
\text { (K32) }\end{array}$ \\
\hline $\begin{array}{l}\text { Turizm Bilincinin } \\
\text { Artırılması ve } \\
\text { Eğitim }\end{array}$ & $\begin{array}{l}\text {-Yerel Halkın } \\
\text { Bilinçlendirilmesi } \\
\text {-Mesleki Eğitim ve } \\
\text { Uzmanlaşma Eğitimlerinin } \\
\text { Planlanması } \\
\text {-İș Ahlakı Eğitimi }\end{array}$ & $\begin{array}{l}\text { "Yerel halkın, turiste nasıl davranması gerektiği öğretilmelidir. } \\
\text { Önce misafirin ağırlanması, sonra kazanç düşünülmelidir." } \\
\text { (K6) } \\
\text { "Turizm meslek eğitimini geliștirmek gerekiyor." (K11) } \\
\text { "Ülke olarak önce tüm sektörlerde olması gerektiği gibi } \\
\text { Turizm sektöründe de ahlaki çalışma ortamı oluşturulması } \\
\text { gerekir." (K41) }\end{array}$ \\
\hline
\end{tabular}


İlker Şahin, F. Özlem Güzel, “Olumsuz Güncel Gelişmelerin ve Krizlerin Türk Turizmine Etkileri: Profesyonel Turist Rehberlerinin Değerlendirmeleri ve Sektörel Çözüm Önerileri”, İstanbul Gelişim Üniversitesi Sosyal Bilimler Dergisi, 7 (2), Ekim 2020, ss. 257-280.

\begin{tabular}{|c|c|c|}
\hline $\begin{array}{l}\text { Kültür Turizmine } \\
\text { Teşvik }\end{array}$ & $\begin{array}{l}\text {-Kültürün Ürün Olarak } \\
\text { sunulması } \\
\text {-Kültür Turizminin Teşvik } \\
\text { Edilmesi } \\
\text {-Kültürel Anadolu } \\
\text { Turlarının Tasarımı } \\
\text {-Uygun Fiyatlı Kültürel } \\
\text { Paket Turların Tasarımı } \\
\text {-Acentelere Ören Yeri } \\
\text { Giriși Desteği }\end{array}$ & $\begin{array}{l}\text { “Kültür turizmine yönelmek, kültür unsurlarımızın } \\
\text { benimsenmesi ve yașatılması gerekiyor." (K1) } \\
\text { “Türkiye Kültür ve Turizm Bakanlığı ilk olarak bu deniz kum } \\
\text { güneş reklamlarından bir vazgeçmeli. Elinizde muazzam bir } \\
\text { tarih ve kültür gücünüz var. Bunları kullanmalıyız.” (K3) } \\
\text { "Kültür Turizmini yapan acentelere getirdikleri turist bașına } \\
\text { bir teșvik verilebilir. Hem gelirin bölgesel dağıllmını sağlayın } \\
\text { hem de Anadolu turlarının satılabilirliğini sağlayın. Acentelere } \\
\text { ören yerlerine girișlerde indirimler yapılabilir." (KT1) }\end{array}$ \\
\hline $\begin{array}{l}\text { Alternatif Turizm } \\
\text { ve } \\
\text { Sürdürülebilirlik }\end{array}$ & $\begin{array}{l}\text {-Alternatif Turizm } \\
\text { Türlerinin Tespit Edilmesi } \\
\text {-Alternatif Turizm } \\
\text { Türlerinin Desteklenmesi } \\
\text {-Doğa, Yat, Kongre, } \\
\text { Etkinlik, Golf Turizm } \\
\text { Türleri İçin Avantajin } \\
\text { Kullanılması } \\
\text {-Sürdürülebilir Turizm } \\
\text { Yönetimi }\end{array}$ & $\begin{array}{l}\text { “Alternatif turizm türleri gelistirilmelidir. Yabancı turist } \\
\text { doğaya yönlendirilmeli, yat turizmi ile seyahat edenlere cazip } \\
\text { imkânlar sunulmalı, yeni festivaller organize edilmelidir." } \\
\text { (K35) } \\
\text { “Türkiye Golf turizmi açısından müsait ortamlara sahiptir. Bu } \\
\text { turnuvaların desteklenmesi, onun haricinde termal turizm } \\
\text { alanında Türkiye'nin çok büyük potansiyeli var." (K1) } \\
\text { "Kongre turizmine uluslararası alanda daha büyük yatırımlar } \\
\text { yapılmalıdır." (K13) } \\
\text { "Termal otellerimizi iyi pazarlamalıyız." (K3) } \\
\text { “Cevreci, hoşgörülü, bilinçli turizm atağı bașlatılmalıdır." (K54) }\end{array}$ \\
\hline $\begin{array}{l}\text { Turistik Ürün } \\
\text { Olușturma ve } \\
\text { Pazarlama }\end{array}$ & $\begin{array}{l}\text {-Uzak Mesafeli Ülkeler İçin } \\
\text { Ürün Geliştirilmesi } \\
\text {-Kombine Turlar Planlama } \\
\text {-İkili Uçuş Anlaşmaları } \\
\text {-Destinasyon Alternatifleri } \\
\text { Oluşturma ve Pazarlama }\end{array}$ & $\begin{array}{l}\text { “Uzak ülkelere uzun süre tatile çıkabilecek olanlara yönelik } \\
\text { ürünler geliștirmemiz lazım. Bu ürünlerin bașında da kombine } \\
\text { turlar gelir. Türkiye artı Fransa, Türkiye artı Tunus, Türkiye } \\
\text { artı Mısır gibi farklı ülkelerle farklı ürünleri bir arada } \\
\text { oluşturan paketler yapmamız lazım." (K1) } \\
\text { “Yeni kitle Arap turiste yönelik tur ve tesis düzenlemeleri } \\
\text { Avrupalı ve Uzakdoğulu turiste yönelik özel turlar ve tesisler } \\
\text { olușturulmalıdır. Yeni turizm destinasyonları } \\
\text { kazandırılmalıdır." (K11, K39) }\end{array}$ \\
\hline $\begin{array}{l}\text { Tanitım } \\
\text { Faaliyetleri }\end{array}$ & $\begin{array}{l}\text {-Tanıtım Ekiplerinin } \\
\text { Oluşturulması } \\
\text {-Rehberlerin Tanıtımda } \\
\text { Aktif Olarak Kullanımı } \\
\text {-Lobicilik } \\
\text {-Yurtdışı Medyası ile Etkin } \\
\text { İletişim } \\
\text {-Film Sponsorluğu } \\
\text {-Tanıtım Faaliyetlerinin } \\
\text { Artırılması } \\
\text {-Bireysel Tanıtım } \\
\text { Faaliyetleri } \\
\text {-Olumlu İmaj Yaratan } \\
\text { Faaliyetler } \\
\text {-Sosyal Medyanın Aktif } \\
\text { Kullanımı } \\
\text {-Sempati Olușturma }\end{array}$ & 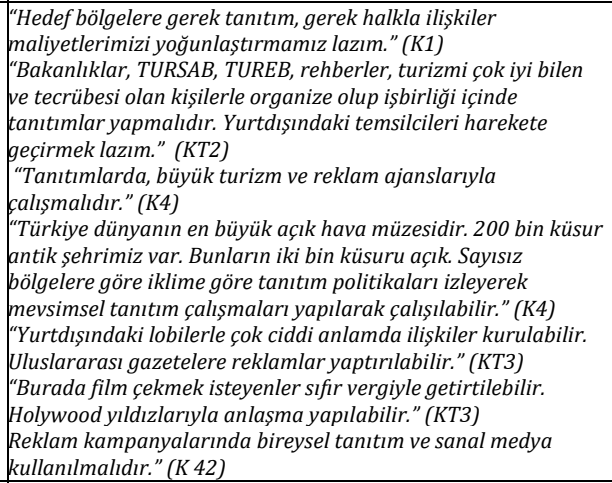 \\
\hline $\begin{array}{l}\text { Hedef Pazar } \\
\text { Çalışmaları }\end{array}$ & $\begin{array}{l}\text {-Hedef Pazar Araştırması } \\
\text {-Hedef Pazarlar Belirleme } \\
\text {-Hedef Pazar } \\
\text { Çeșitlendirme } \\
\text {-İç Pazarın Desteklenmesi } \\
\text { ve Teşvik Edilmesi }\end{array}$ & $\begin{array}{l}\text { "Turizm pazarını zenginleștirmek lazım. Hatta bu amaçla } \\
\text { Uzakdoğu'ya da gitmek lazım. Japonya'dan sadece çok } \\
\text { meraklı olanlar geliyor. 3-5 acente vardır. Çoğaltmak lazım." } \\
\text { (K2) } \\
\text { "Avrupa ile krize giriyoruz. Turizm Bakanlığındaki yetkilileri } \\
\text { nasll olsa Araplar geliyor diyor. Sadece Ortadoğu'ya açılırsak } \\
\text { turizm çöker. Vizyonumuz geniş olmalı." (K3) } \\
\text { "Yerli turizm teşvik edilmelidir." (K52) } \\
\text { "Turizmi ve seyahat etmeyi Türk insanı için lüks olmaktan } \\
\text { çlkartıp ihtiyaç haline getirmeliyiz ki seyahat etsinler." (K36) }\end{array}$ \\
\hline $\begin{array}{l}\text { Destinasyon } \\
\text { Markalaşması }\end{array}$ & $\begin{array}{l}\text {-Markalama Çalışmaları } \\
\text {-Mikro Destinasyon } \\
\text { Bazında Tanıtım }\end{array}$ & $\begin{array}{l}\text { "Türkiye Cumhuriyeti'nde kendi bașına markalaşmış } 3 \text { tane } \\
\text { șehir var. } 3 \text { tane yer var: İstanbul, Kapadokya, Bodrum. } \\
\text { Antalya'nın bir markası yok. Antalya'daki otelleri biliyor } \\
\text { Avrupalılar. Instagram sayesinde kendi başına marka olan } \\
\text { bir Kapadokya var." (KT3) } \\
\text { "Bugün Ittalya'ya giderken siz bir otel ismi vermiyorsunuz. } \\
\text { Ben Floransa'ya gidiyorum diyorsunuz. Ama Antalya'ya giden } \\
\text { adam ben Wow Topkapı'ya gidiyorum diyor. " (KT3) }\end{array}$ \\
\hline
\end{tabular}




\begin{tabular}{|c|c|c|}
\hline $\begin{array}{l}\text { Etkinlik } \\
\text { Planlama }\end{array}$ & $\begin{array}{l}\text {-Temalı Etkinliklerin } \\
\text { Tasarımı } \\
\text {-Kültürel Verilerin } \\
\text { Etkinliğe Dönüștürülmesi }\end{array}$ & $\begin{array}{l}\text { "Noel Baba'nın ihracatı yapılmalı. Diyeceğiz ki; Noel'ini de } \\
\text { gel bu topraklarda kutla." (K3) } \\
\text { "Antalya'da Perge dünyada ilk biranın üretildiği yer. } \\
\text { Dünyada ilk birayı biz keșfetmişiz düşünebiliyor musun? Bira } \\
\text { festivali yapın. Kapadokya'da șarap festivali yapalım insanlar } \\
\text { gelsin, burada bolca güzel vakit geçirsinler, mutlu olsunlar" } \\
\text { (KT3) }\end{array}$ \\
\hline $\begin{array}{l}\text { Arz } \\
\text { Yapılanması }\end{array}$ & $\begin{array}{l}\text {-Otel Standartlarının } \\
\text { Gözden Geçirilmesi } \\
\text {-Sigorta Sistemi Kurulması } \\
\text {-Herşey Dâhil Sisteminin } \\
\text { Kaldırılması } \\
\text {-Tur Kalite Standartlarının } \\
\text { Yükseltilmesi } \\
\text {-Acelecilikte Dijital } \\
\text { Pazarlama ve } \\
\text { Programlama } \\
\text {-Yerli Tur Operatörlerinin } \\
\text { Kurulması }\end{array}$ & $\begin{array}{l}\text { "Alanya, Kuşadası gibi yoğunlaşmanın yüksek olduğu ılıman } \\
\text { iklime sahip bölgeler yenilenme aşamasına gelmiştir, } \\
\text { standardını yitirmis oteller üçüncü yaş turizmi köylerine } \\
\text { çevrilebilir." (KT1) } \\
\text { "Turist sigortası sistemi oluşturulmalıdır." (K13) } \\
\text { "Her șey dâhil sistemin ülke çapında kaldırılması hatta } \\
\text { yasaklanması gerekmektedir. " (K32) } \\
\text { "Kalite yükseltilmelidir. Turizmde alışverişe dayalı turlar } \\
\text { kaliteyi düşürüyor." (K46) } \\
\text { "Hemen reform faaliyetlerine başlanıp dijitalleşme sürecine } \\
\text { gidilmeli. Programlama ve dijital pazarlama bilmeyen } \\
\text { acentecilerin aç kalacağı bir gerçek. Yurtdışında yerli tur } \\
\text { operatörümüz olmalıdır." (K25, K44) }\end{array}$ \\
\hline $\begin{array}{l}\text { Finansal } \\
\text { Destek }\end{array}$ & $\begin{array}{l}\text {-Vergi Affi } \\
\text {-Faizsiz Kredi İmkânı } \\
\text {-Tur Ücretlerinde İndirim }\end{array}$ & $\begin{array}{l}\text { "Yatırımcıya hiç değilse vergi affı veya ödemelerinde kolaylık } \\
\text { yapılmalıdır. Hediyelik eşya satan esnafa kadar turizm } \\
\text { çalışanı destek paketi insani ölçülerde hazırlanmalıdır." } \\
\text { (K58) } \\
\text { "Turizm çalıșanları devlet destekli faizsiz kredilerle } \\
\text { desteklenmelidir." (K60) } \\
\text { "Müze, tur fiyatlarında indirim olmalı" (K42) }\end{array}$ \\
\hline
\end{tabular}

Son yıllarda Avrupalı turistler konusunda yaşanan kayıplara istinaden hedef pazar çalışmalarının gerçekleştirilmesi teması da öne çıkan bir diğer önemli unsur olmuştur. Bu bağlamda hedef pazar araştırmalarına dikkat çeken katılımcılar, hedef pazarların planlı bir şekilde belirlenmesi ve çeşitlendirilmesi gerektiğini vurgulayarak tek pazarlara bağlı kalmanın yaşattığı kayıplara ilişkin bir çıkış noktası göstermektedirler. Rehberler yalnızca belirli pazarlara bağlı kalma stratejisinin gerek turizm sektörü gerekse icra ettikleri rehberlik mesleği açısından önemli bir risk taşıdığını ifade etmiş; bununla birlikte turizmde hitap edilen pazar yelpazesinin genişletilerek alternatif turist kitlelerinin destinasyona çekilmesi konusunda planlı çalışmalar yapılması gerektiğinin altını çizmektedirler. İç pazarın desteklenmesi ve teşvik edilmesi konusu da ek olarak hedef pazar çalışmaları ana temasında yer almıştır. Turist rehberlerine göre yerli turistler önemli bir alternatif turizm pazarıdır ve kesinlikle ihmal edilmemelidir. Buna göre yurtdışından gelen turist hareketlerinde meydana gelebilecek olumsuz yönlü dalgalanmalarda veya çeşitli politik, doğal ve benzeri sebepler neticesinde belirli bir pazara hitap eden destinasyonlarda ziyaretçi ve geceleme sayısı bazında oluşabilecek dönemsel düşüşlerde iç turizmin adeta kurtarıcı olabileceği öngörülmüştür.

Destinasyon markalaşmasının önemine de dikkat çeken rehberler, destinasyonlarda marka çalışmalarına önem verilmesi gerektiğini ve mikro destinasyon bazında tanıtımların planlı bir şekilde yapılmasını öneri olarak sunmuşlardır. Bu bağlamda etkinlikler, turistleri ülkeye çekme konusunda önemli birer faaliyet alanı olarak ön plana çıkmıştır. Rehberler, temalı etkinliklerin tasarımı ve kültürel verilerin çeşitli planlar dâhilinde etkinliğe dönüștürülmesini önermektedir. Rehberlere göre turistlere hitap edecek etkinlikler ve aktiviteler gerek yerel kültüre gerekse pazarın hitap ettiği pazarın özelliklerine uygun olarak tasarlanarak, deneyim pazarlaması kapsamında yapılacak çalışmalarla tanıtılmalıdır. Turist rehberleri, bu sayede destinasyonların rekabet avantajı elde edeceğini, destinasyonun rakipleri arasında farklılaşarak daha fazla ilgi çekeceğini ve böylece ziyaretçi sayılarında istikrarlı artış sağlanabileceği konusunda hemfikirdirler. 


\section{Sonuç}

Son yıllarda Türkiye'de yaşanan beklenmedik gelişmelerin neden olduğu olumsuz sonuçlara ilişkin rehber görüşlerinin alındığı bu çalışmada turizm, kırılgan ve rekabetçi yapıya sahip olan, ikame edilebilir ürünleri barındıran ve ülke imajının etkin rol oynadığı bir sektör olarak ele alınmıştır. Turizm sektörü kırılgan ve hassas yapısı nedeniyle savaş, salgın tehlikesi, terör, sosyal atmosferden çok kolay ve hızlı etkilenmektedir.

Turizmin rekabetçi bir yapıya sahip olması ise olumsuz gelişmelerin gölgesinde faaliyet gösteren ve bağımsız üniteleri bünyesinde barındıran turizm sektöründe, mevcut sınırların ötesine geçilerek uluslararası düzeyde rekabet edilmesinin zorunlu hale gelmesini ifade etmektedir. Türkiye'de yaşanılan her bir olumsuz gelişme sonucunda turistlerin Yunanistan, İspanya, İtalya gibi Akdeniz çanağındaki diğer ülkelere tatil amaçlı gitmeleri bu duruma örnek olarak verilebilir. Benzer şekilde turistlerin huzur ve güven atmosferi içinde tatil yapmayı tercih ettikleri vurgusu önemli bir boyut olarak ortaya çıkmıştır. Turizmde var olan turistik ürünlerin ikame edilebilir olması yani Ünlüönen ve diğerlerinin de (2009) belirttiği gibi "turistik tüketimin, zorunlu olmayan tüketim olması" durumu yine olumsuz güncel gelişmeler karşısında turizmin karakteristik özelliği olarak vurgulanmıștır.

Türkiye'de turizm sektörünün olumsuz gelişmeler nedeni ile içinde bulunduğu duruma yönelik çözüm önerileri bağlamında oldukça zengin bulgular elde edilmiştir. Sonuçlar değerlendirildiğinde içerik bakımından öne çıkan güvenlik vaadi temasının çalışma amacı doğrultusunda ortaya çıan en önemli bulgular arasında olduğu anlaşılmaktadır. Aras da (2017) benzer şekilde turizm politikalarının turistlerin güvenlik ihtiyaçlarına yönelik özgün yaklaşımlar içermesi gerektiğini ve turist gönderen ülkelerdeki acentelerin ve turistlerin turizm bölgesi seçiminde güvenlik unsurunun önemli bir belirleyici olduğunu vurgulamaktadır. Güvenlik ve destinasyon seçimi ilișkisini inceledikleri çalıșmalarında Bayhan ve Ünlüönen de (2016) turizm bölgelerinde güvenlik tedbirlerinin turistlerin fark edebileceği boyutlarda alınması gerektiğini belirtmektedir. Aras (2017), bu bağlamda turizm bölgelerinde estetik görüntüyü bozmayacak şekilde yaya, bisikletli, binek araçlı, atlı vb. turizm polislerinin yer almasını, giriş noktası yoğunluklu güvenlik uygulamalarını, müze ve ören yerlerine sırt çantası ile girilmesinin yasaklanmasını örnek olarak vermektedir.

Politik ilişkilerin kurulması yine güncel olumsuz gelişmeler ve krizlere yönelik olarak alınması gereken önemli bir karar olarak ortaya çıkmıştır. Bunu destekler nitelikte Atasever ve Bahar da (2017) küreselleşme olgusunun, ülkeleri birbirine bağımlı kıldığını, sosyo-ekonomik ve politik gelişmelere duyarlı hale geldiğini ve politik koşulların turizm sektörü için belirleyici hale geldiğini vurgulamaktadır. Öte yandan, kriz ve algı yönetimi, teşvikler, iç turizmi, yeni segmentlere yönelmeyi, çoklu paydaş planlaması ve krizden muaf ürün sunumlarını çözüm olarak önermektedirler.

Turizm politikalarında yapılanma konusu içinde politikaların revize edilmesi, stratejilerin planlanması, komitelerin oluşturulması ve teşviklerin sorgulanması önemli bir boyut olarak ortaya çıkmıştır. Zira destekler şekilde Kültür ve Turizm Bakanlığı tarafından düzenlenen 3. Turizm Şurasında da bakanlık koordinasyonunda oluşturulacak söz konusu yapı tarafından riskler önceden tespit edilerek, etki ve olasılıklarının azaltılmasına yönelik eylem planları hazırlanması, olası bir kriz durumunda seri hareket edilebilmesi için bölgesel/yerel bazda da karar mekanizmalarının oluşturulması öneri olarak sunulmuştur (Turizm Politikaları Komisyonu Raporu, 2017). Politik ilişkilerin uzlaşmacı düzeyde ve etkin bir şekilde gerçekleştirilmesi de yine özellikle turizm pazarları olan ülkeler açısından önem arz etmektedir. Çünkü turizm sektörü politik bunalımlardan en hızlı şekilde etkilenen sektörlerin başında yer almaktadır ve ülkelerle vize formaliteleri, turizm yatırımları gibi konularına ilișkin anlașmalar yapılarak ülkeler 
arası ilişkiler güçlendirilmelidir. Bu bağlamda Kültür ve Turizm Bakanlığı, Dış İlişkiler ve AB Komisyon Başkanlığı gibi kurumlara önemli görevler düşmektedir.

Gerek kriz dönemlerini gerekse kriz dışındaki dönemleri ilgilendiren turisti koruyan yasal önlemlerin artırılması, turizm operatörlerinin kontrolü, komisyonların denetimi/faturalandırılması ve kalifiye çalışanların korunması konuları çalışma kapsamında ortaya çıkarılan alt temalar arasındadır. Söz konusu alt temalar düzenleyici önlemlerin alınması bașlığı altında değerlendirilmiștir. Benzer șekilde "turizm bilincinin artırılması ve eğitim konusu", "arz yapılanması", "kültür turizminin teşvik edilmesi" ve "alternatif turizm ve sürdürülebilirlik" de yine öneri olarak bu çalışmada ortaya çıkmıştır. 3. Turizm Şurasında da turizm destinasyonlarında turizm bilincinin ve kültürünün oluşturulması için turizm konusunda farkındalığın arttırılması; doğal, tarihî ve kültürel varlıkların sürdürülebilir turizm ilkeleri doğrultusunda değerlendirilerek bu konuda toplum temelli eğitimin sağlanması gerektiği; turizmin ülke geneline ve 12 aya yayılmasını sağlamak amacıyla sağlık, kış, golf, eko turizm ve benzeri ürünler ile turizm bölgelerinin ve turizm ürün çeşitliliğinin çoğaltılması teşvik edilmesi; çevrenin korunması, toplam kalite düzeyinin yükseltilmesi, vb. hususlara turizmde sürdürülebilir gelişme için önem verilmesi gerekliliği belirtilmiştir (Kültür ve Turizm Bakanlığı Turizm Politikaları Komisyonu Raporu, 2017). Bu çalışmada da yerel halkın bilinçlendirilmesi, mesleki uzmanlaşma ve iş ahlakı eğitimine yönelik turizm bilincini artırma eğitimlerinin önemi; alternatif turizm türlerinin tespiti ve desteklenmesi, sürdürülebilir turizm yönetiminin uygulanmasının önemi ve yine kültürün ürün olarak sunulması, kültürel Anadolu turlarının tasarlanması, uygun fiyatlı kültür turlarının tasarlanmasının önemi temalar bağlamında ortaya çıkmıştır. Türkiye'nin benzersiz ve özgün kültürel altyapısı, korunmuş/doğal alanlarının varlığı kriz dönemlerinde de Türkiye'nin vazgeçilmez bir destinasyon olmasının kapısını açacaktır.

Araştırma neticesinde elde edilen bulgulara göre turist rehberleri, Türkiye'nin yeni turistik ürün oluşturma ve pazarlama stratejileri geliştirmesi gerektiği görüşünü desteklemekte ve bu bağlamda atılacak adımlara ilişkin çeşitli öneriler sunmaktadır. Rehberler, krizler ve turizm hareketliliğini doğrudan veya dolaylı yollardan etkileyen olumsuz gelişmeler karşısında alınacak önlemlerin başında 'farklılașma', 'ürün çeşitlendirme', 'ikili uçuş anlaşmaları yoluyla paket tur alternatifleri oluşturma' ve 'destinasyon çeşitlendirmesi' gibi günümüzün rekabetçi koşullarında Türkiye'yi bir adım öne taşıyacak potansiyele sahip uygulamaların hayata geçirilmesi gerektiğini belirtmektedirler. Bir bütün olarak değerlendirildiğinde rehberler tarafından sunulan önerilerin Porter'ın (1980) öne sürdüğü 'farklılaşma' stratejisi ile 3. Turizm Şurası'nda alınan kararlar ile örtüştüğü ve ileriye dönük bir dizi önlemi içerdiği görülmektedir. Şura kararları incelendiğinde bakanlık bünyesinde AR-GE biriminin kurularak turizmdeki küresel ve bölgesel gelişmelerin izleneceği, toplanacak verilerin değerlendirileceği, yeni turizm ürünlerinin geliștirilmesi ve çeșitlendirilmesinin sağlanacağı bir altyapının oluşturulmasına öncelik verildiği görülmektedir. Bununla beraber sektör kuruluşları arasında çeşitli işbirliği çalışmaları yürütülerek uygun fiyatlı uçuşların ve tarifeli seferlerin teşvik edilmesi hedeflenmektedir (Kültür ve Turizm Bakanlığı Turizm Politikaları Komisyonu Raporu, 2017). Alanyazın incelendiğinde, turizmde ürün çeşitlendirmenin bölgenin sahip olduğu zenginlikleri iyi değerlendirmek ve turist sayısını artırmak için farklı pazarların beklentileriyle uyumlu, ihtiyaçlara cevap veren nitelikte yeni ve rekabetçi turistik ürün ve hizmetler sunulmasını içerdiği; bunların farklı alternatifler içeren geniş bir seçim yelpazesiyle desteklenerek destinasyonların büyüme hedefleriyle doğru orantılı olarak şekillendirilmesi gerektiği görülmektedir (Mucuk, 2001; Buluç, 1997, Önce, 1991). Öte yandan Kozak ve Kızılırmak (2006) ülkelerin yeni destinasyonlar ile rekabet edebilmesinin, sundukları turizm ürünlerinin farklılığı ve özgünlüğünü sağlamaktan geçtiğini belirtmekte; bu durum karşısında ise turistik ürün 
çeşitlendirmesinin artık bir zorunluluk haline geldiğini vurgulamaktadır. Araştırmacılar, Kültür ve Turizm Müdürleri ile yaptıkları görüşmeler neticesinde tüketici ihtiyaçlarının değişimi kapsamında 'turizmin çeşitlendirme politikalarının uygulanması', 'Türk turizminde yeni turistik ürünlerin ön plana çıkarma' temalarını elde etmişlerdir. Bu temaların içeriği incelendiğinde, bulguların Kozak ve Kızılırmak'ın sonuçlarıyla net olarak örtüştüğü ve öne çıkan unsurları daha detaylı bir şekilde vurguladığı görülmektedir. Bu bağlamda araştırma kapsamında rehberlerin, modern çağın pazarlama anlayışına ve günümüz şartlarına ayak uyduran ve önceki çalışmalarda vurgulanan noktalara yönelik tavsiyelerde bulunduğu dikkat çekmektedir. Özellikle uzak ülkelerden gelen ve seyahate çıkmadan önce geniş bir coğrafyayı ziyaret etme planı olan turistlere yönelik için de Türkiye'nin de bulunduğu zincir kombine paket turların oluşturulması, Mısır, Yunanistan, Balkanlar, Fas, Kafkaslar, Orta Avrupa gibi popüler ve merak uyandıran yakın ülke ve destinasyonların söz konusu tur kombinasyonlarına Türkiye ile birlikte dâhil edilmesi ve bunların etkin bir biçimde pazarlanması, havayolu firmalarıyla anlaşmalar yapılarak ulaşımda kolaylık, çeșitlilik ve fiyat avantajının sağlanarak ülkemizin daha cazip hale getirilmesi rehberlerin en önemli önerileri arasında yer almaktadır.

Rehberler tarafından sunulan sektörel çözüm önerileri arasında öne çıkan bir diğer konu, turizm kapsamında yapılması öngörülen ve önceki önerileri tamamlayıcı nitelikte olan tanıtım faaliyetleridir. Araştırma bulguları, rehberlerin tanıtım faaliyetleri kapsamında oldukça geniş kapsamlı ve detaylı önerilerde bulunduğuna dikkat çekmektedir. Türk turizminin krizlere daha dayanıklı hale gelmesi ve her koşulda sürekliliğinin sağlanmasının ancak yoğun ve etkili tanıtım stratejisiyle mümkün olacağını öne süren rehberler, yurtdışında lobicilik faaliyetlerine hız verilmesi, yurtdışında medyanın gücünden faydalanılması, sosyal medyanın aktif kullanılması, Türkiye'ye karşı sempati oluşturacak faaliyetlerin yapılması, yeni bir Turizm TV kanalının kurulması, kitleleri etkisi altına alacak potansiyeldeki filmlerin sponsorluğunun üstlenilmesi gerektiğine vurgu yapmaktadırlar. Öneriler arasında dikkat çeken bir diğer unsur ise rehberlerin tanıtımda aktif rol üstlenerek, yurtdışındaki fuarlarda ve tanıtım kampanyalarında etkin görevler üstlenmeye sıcak bakmasıdır. Araştırma sonuçları, rehberlerin oldukça vizyoner bir bakış açısıyla yenilikçi ve geleceğe dönük stratejiler konusunda hedef pazarlara yönelik çözüm önerileri sunduklarını ortaya koymuştur. Rehberler, Türkiye'de turizmin sadece belli başlı pazarlara bağımlı şekilde sürdürülmesini son derece riskli olarak görmekte ve mevcut pazarlarda meydana gelecek olası krizlerin sektörde telafisi uzun zaman alan derin olumsuz etkiler yarattığı fikrini desteklemektedir. Rehberler, sektörün 27 batı ülkesine dayalı bir pazar portföyünden; belirli bir plan dâhilinde ön çalışmaları yapılmış yeni pazarlarla çeşitlendirilmesi gerektiğine işaret etmektedir. Bu önerilerin, 19.07.2017-10.07.2018 tarihleri arasında Kültür ve Turizm Bakanlığı görevini yürüten sayın Numan Kurtulmuş'un 3. Turizm Şurası öncesi verdiği demeçle net bir biçimde örtüştüğü görülmektedir: "Başta Uzak Doğu Asya olmak üzere Çin, Hindistan, Güney Kore ve Japonya bizim yeni alternatif pazarımız olarak görülüyor. Bu ülkelerin ortak özelliği çok geniş bir yeni orta sınıfa sahip olmaları... Burada alım gücü yüksek, turizm başta olmak üzere birç̧ok alanda harcama yapmaya müsait geniş bir pazar var. Inş̧allah bu anlamda pazar çeșitlendirmesini sağlayacağız. Yaklaşık bir ay evvel Çin'de temaslarda bulunduk. Önümüzdeki günlerde de bakanlık olarak Dalaman'da Hindistan'dan yaklaşık 600 tur operatörünün yer alacağı toplantıya katılacağız. Uzak Doğu Asya ile ilgili her kapıyı açmaya gayret edeceğiz. Burada dünya nüfusunun 3'te 1'i bulunuyor. Burası bizim için önemli ve cazip bir pazar. Buraları Avrupa pazarında zaman zaman yaşadığımız sıkıntıları hafifletmek ve orta vadede çok geniş bir kitleye hitap etmek bakımından da önemsiyoruz. " (Anadolu Ajansı, 2017).

Hedef pazar çalışmaları boyutu altında, rehberler, turizmde B planı olarak, iç turizmin canlandırılması ve desteklenmesi gerektiği görüşünde hemfikirdirler. Hedef 
pazarlar büyük ölçüde çeşitlendirilse dahi meydana gelebilecek küresel krizler karşısında Türk turizminin yerli turistler sayesinde bir nebze de olsa ayakta kalabileceği görüşünü destekleyen rehberlere göre, iç turizmi canlandırarak Türk insanı için seyahat etmeyi ve tatili bir lüks olmaktan çıkarıp ihtiyaç haline dönüştürmek gerekmektedir. Destinasyon markalaşması boyutu altında elde edilen alt temaların, araştırmanın en özgün bulguları arasında olduğu görülmektedir. Rehberler destinasyon markalaması kapsamında oldukça ilginç bir noktaya dikkat çekerek, turistlerin tatile çıkarken genellikle Türkiye'de bir destinasyonun adını bilmeden geldiğini, bunun yerine konaklayacağı tesisin adını tatiliyle özdeşleștirerek seyahat ettiğini belirtmektedir. Bu görüșe göre turistler, gidecekleri tesisin konumlandığı tatil destinasyonunu ikinci plana atmakta veya destinasyonun adını net olarak bilmemektedir. Bu durum Türkiye'de destinasyon markalamasının yetersiz olduğuna ve mevcut destinasyonların ise markalaşma sürecini bütünsel olarak tamamlamadığına işaret etmektedir. Rehberlere göre mikro ve makro düzeyde markalama çalışmaları yapılarak destinasyonların bilinirliğinin artırılması, turistlerin zihninde destinasyonların ön plana çıkarılması ve tatillerini doğrudan destinasyonla ilişsilendirmeleri sağlanmalıdır. Bu sonuç, Hassan ve diğerleri (2011) tarafından, Belek ve Kemer'i ziyaret eden turistler üzerinde yaptıkları araştırma bulgularını destekler niteliktedir. Araştırmacıların Türkiye denildiğinde akla nelerin geldiği sorusuna aldıkları yanıtlar incelendiğinde, ilk sırada, turizm, güneș ve otellerin olduğu ortaya çıkmıștır. Katılımcıların yalnızca birkaçının İstanbul ve Antalya destinasyonlarını belirttiği görülmüştür. Rehber önerilerini destekleyen söz konusu bulgulardan da anlaşllacağı üzere ülkemizde destinasyonların daha bilinir hale gelmesi, dünyadaki rakiplerine karşı rekabet üstünlüğü elde etmesi ve konumlandığı segmentteki başarısının ve gelişiminin ivme kazanması için uluslararası çapta markalaşma süreçlerinin planlanması ve buna yönelik yeni stratejilerin uygulamaya konması sonucu ortaya çıkmıştır. Rehberler, ülkemizin sahip olduğu tarihi ve kültürel dokuya dikkat çekerek, dünyanın hiçbir yerinde bulunmayan ve sadece ülkemizi ziyaret edenlerin deneyimleyebileceği bazı belirli öğelerin ön plana çıkarılarak, temalı festival, şölen, karnaval ve benzeri etkinliklerle tanıtılması gerektiğine işaret etmektedir. Böylelikle geçmişte ülkemizde yaşamış, dünyada önem taşıyan ünlü kişilerin veya dünyada ilk ülkemizde gerçekleşmiş faaliyetlerin Türkiye ile özdeşleşmesi ve destinasyonlarımızla ilişkilendirilmesi sağlanacaktır. Rehberler bu konuda belirli kişileri ve olayları örnek göstererek (St. Nicholas, ilk biranın Perge'de imal edilmesi, şarap kültürü ve üretimin Kapadokya'da gelişim göstermesi vb.) temalandırılmış kapsamlı etkinlikler yoluyla destinasyon pazarlamasının mümkün olacağını belirtmektedirler. Rehberlerin dikkat çektiği bir diğer konu turizmdeki arz yapılanması kapsamında otel standartlarının ve çeşitli uygulamaların revize edilmesidir. Rehberler özellikle turist trafiğinin ve iklimin ılıman olduğu bölgelerde artık yenilenme aşamasına gelmiş otellerin yenilenmesi gerektiğini vurgulamaktadır. Bu sonucu literatür taramasında destekleyen çalışmalar da mevcuttur (Şahin vd., 2017; Güzel ve Güzel, 2016; Güzel, 2014). Bu durum turistlerle yoğun iletişim halinde olan ve onların beklentilerine hakim olan rehberlerin öne sürdüğü önerilerin bir an önce hayata geçirilmesi gerektiğine işaret etmektedir. Bunlara ek olarak Rehberler, sigorta sisteminin kurulması, otel konaklama konseptlerinin revize edilmesi, turlarda kalite standartlarının yükseltilmesi, yerli tur operatörlerinin kurulması, vergi affı ve faizsiz kredi imkânı sağlanması ve tur ücretlerinde indirilme gidilmesini önermektedirler. Sonuç olarak güvenlik, emniyet, barış ortamı, toplumsal, siyasi ve politik istikrar, turizmin gelișebilmesi için gerekli olan ön koşullardır ve bu unsurların eksik olduğu destinasyonlar, çekici/kaliteli kaynak ve ürünlere sahip olsa da uluslararası rekabet güçlerini kaybetmektedirler. Bu bağlamda bu çalışmadan turizm paydaşı olarak rehberlerden elde edilen bu değerli önerilerin uygulamada yer bulması Türkiye turizminin çok sert düşüşler yaşamaması açısından büyük önem arz etmektedir. 
İlker Şahin, F. Özlem Güzel, “Olumsuz Güncel Gelișmelerin ve Krizlerin Türk Turizmine Etkileri: Profesyonel Turist Rehberlerinin Değerlendirmeleri ve Sektörel Çözüm Önerileri”, İstanbul Gelişim Üniversitesi Sosyal Bilimler Dergisi, 7 (2), Ekim 2020, ss. 257-280.

\section{KAYNAKÇA}

ANADOLU AJANSI (2017, 25 Ekim). Ekonomi Gazetecileri, Turizm Bakanı Numan Kurtulmuş ile Buluştu. Erişim Adresi: http://www.tuyed.org.tr/kurtulmus-turizmdepazar-cesitlendirmesini-hedefliyoruz

ANDERSON, B. A. (2006). Crisis management in the Australian Tourism Industry: preparedness, personnel and postscript. Tourism Management, 27(6), 1290-1297.

ARAS, H. (2017). Türkiye'de turizm güvenliği sorunu, Hitit Üniversitesi Sosyal Bilimler Enstitüsü Dergisi, Yıl 10, Sayı 1, Haziran 2017, 585-610.

ATASEVER, G. ve BAHAR, O. (2017). Medya bağlamında politik istikrarsızlıkturizm ilişkisi. Güvenlik Bilimleri Dergisi, 6(1), 33-56.

BAYHAN, İ. ve Ünlüönen, K. (2016), Turist tercihlerinde güvenliğe ilișkin tutumlarının etkisi: Bir alan araştırması, Elektronik Sosyal Bilimler Dergisi, 15(56), 1-20.

BULUC, G. T. (1997). Turistik ürün pazarlama politikası ve planlaması ve bir pazarlama stratejisi olarak turistik ürün çeșitlendirmesi, Anatolia Turizm Araștırmaları Dergisi, 1-2 (8), 12-17.

DE SAUSMAREZ, N. (2007). Crisis management, tourism and sustainability: The role of indicators. Journal of Sustainable Tourism, 15(6), 700-714.

DOĞRULUK PAYI, (2016). 2015-2016 Dönem Raporu. Erişim Adresi: https://www.dogrulukpayi.com/dosyalar/rapor/DP_YillikRapor_2015-2016.pdf, Erişim Tarihi: 22.02.2018.

ENDERS, W.; SANDLER, T. and PARISE, G. F. (1992). An econometric analysis of the impact of terrorism on tourism. Kyklos, 45(4), 531-554.

FAULKNER, B. (2001). Towards a framework for tourism disaster management. Tourism Management, 22 (2), 135-147.

FINK, S. (1986). Crisis management: Planning for the inevitable. New York: American Association of Management.

GLAESSER, D. (2006). Crisis management in the tourism industry. Routledge.

GÜZEL, F. Ö. ve EHTIYAR V. R.; GÜDEKLI İ. A. (2016). Terör olaylarının medya üzerinden turizme etkisi: BBC Sultanahmet terör saldırısı haberi eleştirel söylem analizi, 3. Uluslararası Çin'den Adriyatik'e Sosyal Bilimler Kongresi, Antalya, Türkiye, 28-30 Ekim.

GÜZEL B. and GÜZEL F. Ö., (2016). Evaluating the resort hotel attributes via online guest reviews, International Academic Conference on Social Sciences and Humanities, 30-31 Aralık. Prag, Çek Cumhuriyeti.

GÜZEL F. Ö. (2014). Marka itibarını korumada şikâyet takibi: Çevrimiçi seyahat 2.0 bilgi kanallarında bir uygulama, Internet Uygulamaları ve Yönetimi Dergisi, 1, (5-19).

HASSAN, A. T.; DEMIRÇIVI, M. B. ve YEȘiLTAȘ, M. (2011). Belek ve Kemer'i ziyaret eden yabancı turistlerin görüşleri ve destinasyon pazarlaması. Ticaret ve Turizm Eğitim Fakültesi Dergisi, (1), 37-60.

HEWSON, C. (2010). Internet mediated research and its potential role in facilitating mixed methods research. İçinde S. N. Hesse-Biber \& P. Leavy (Editörler) Handbook of Emergent Methods, ss. 543-570. Newyork: Guilford.

KOZAK, M. A. ve KIZILIRMAK, İ. (2006). Turistik ürün çeşitlendirmesi: Kültür ve turizm müdürleri görüşlerine dayalı bölgesel yaklaşımlar. Mustafa Kemal Üniversitesi Sosyal Bilimler Enstitüsü Dergisi, 3(5), 1-24.

KÜLTÜR VE TURIZM BAKANLIĞI (2020). Şubat 2020 Sınır Bülteni, https://yigm.ktb.gov.tr/TR-9851/turizm-istatistikleri.html, Erişim Tarihi: 10.04.2020. 
İlker Şahin, F. Özlem Güzel, “Olumsuz Güncel Gelişmelerin ve Krizlerin Türk Turizmine Etkileri: Profesyonel Turist Rehberlerinin Değerlendirmeleri ve Sektörel Çözüm Önerileri”, İstanbul Gelişim Üniversitesi Sosyal Bilimler Dergisi, 7 (2), Ekim 2020, ss. 257-280.

KÜLTÜR VE TURİZM BAKANLIĞI (2019). Turizm Gelir, Gider ve Ortalama Harcama Raporu. Kültür ve Turizm Bakanlığı, Erişim adresi: https://yigm.ktb.gov.tr/TR249709/yillik-bultenler.html, Erişim Tarihi:10.04.2020.

KÜLTÜR VE TURIZM BAKANLIĞI (2017). Turizm Politikaları Komisyonu Raporu. 3. Turizm Şurası, Ankara, Erișim adresi: http://turizmsurasi.kulturturizm.gov.tr/TR204570/turizm-politikalari-komisyonu-sonuc-raporu.html, Erișim Tarihi:23.02.2018.

LAWS, E. and PRIDEAUX, B. (2005). Tourism crises: Management responses and theoretical insight. Psychology Press.

LEPP, A. and GIBSON, H. (2003). Tourist roles, perceived risk and international tourism. Annals of Tourism Research, 30(3), 606-624.

MANN, C. and STEWART, F. (2003) Internet interviewing in Gubrium. İçinde: J.F. \& Holstein J.A. (Editörler), Postmodern Interviewing, ss. 81-105, Thousand Oaks, Ca.: Sage Publications.

MCKERCHER, B. and HUI, E. L. (2004). Terrorism, economic uncertainty and outbound travel from Hong Kong. Journal of Travel \& Tourism Marketing, 15(2-3), 99115.

MUCUK, İ. (2001). Pazarlama ilkeleri. İstanbul: Türkmen Kitabevi.

ISAAC, R. K. and VELDEN, V. (2018). The German Source Market Perceptions: How Risky Is Turkey to Travel to?, International Journal of Tourism Cities, 4(4), 429-451.

ÖNCE, G. (1991). Turizmde pazarlama stratejileri ve alternatif bir pazarlama stratejisi olarak yeni ürün-yeni pazarların Türkiye açısından önemi ve değerlendirilmesi. II. Ulusal Turizm Kongresi. 21-23 Kasım, Kuşadası.

PARSONS, W. (1996). Crisis management. Career Development International, 1(5), 26-28.

PORTER, M. E. (1980). Competitive strategy: Techniques for analyzing industries and competitors, (267). New York: Free Press.

RICHTER, L. K. (1983). Tourism politics and political science: A case of not so benign neglect. Annals of Tourism Research,10(3), 313-15.

RITCHIE, B. W. (2004). Chaos, crises and disasters: a strategic approach to crisis management in the tourism industry. Tourism Management, 25(6), 669-683.

SAHIN, I.; GULMEZ, M. and KITAPCI, O. (2017). E-complaint tracking and online problem-solving strategies in hospitality management: Plumbing the depths of reviews and responses on Tripadvisor. Journal of Hospitality and Tourism Technology, 8(3), 372394.

SARIÇAY, S. S. ve ÜNAL, M. (2014). Krizlerin turizm sektörü üzerindeki etkileri. Ar-Ge Bülten. İzmir Ticaret Odası. Erișim adresi: http://izto.org.tr/demo_betanix/uploads/ cms/yonetim.ieu.edu.tr/6426_1480068560.pdf

SEYMOUR, M. and MOORE, S. (2000). Effective crisis management: World-wide principles and practice. Cassell.

SHIEFFIELD UNIVERSITY (2012). Email interviews. Learning \& Teaching Services, Shieffield Üniversitesi, Erișim adresi:https://www.sheffield.ac.uk/lets/strategy/resources/evaluate/general/methods -collection/emailinterviews, Erişim Tarihi: 20.03.2018.

SÖNMEZ, S., F. and TARLOW, P. (1997). Managing tourism crises resulting from terrorism and crime. International Conference on War, Terrorism, Tourism: Times of Crisis and Recovery, Dubrovinik, Croatia, September 25-27.

TURIZM DATA BANK (2019). Paket Tur Pazarı: Türkiye ve Antalya Raporu. Turizm Data Bank. Erişim adresi: http://turizmdatabank.com/turizm-arastirmalari/paket-tur-pazari-turkiye-ve-antalya, Erişim Tarihi: 08.04.2020. 
İlker Şahin, F. Özlem Güzel, “Olumsuz Güncel Gelişmelerin ve Krizlerin Türk Turizmine Etkileri: Profesyonel Turist Rehberlerinin Değerlendirmeleri ve Sektörel Çözüm Önerileri”, İstanbul Gelişim Üniversitesi Sosyal Bilimler Dergisi, 7 (2), Ekim 2020, ss. 257-280.

TURIZM GÜNLÜĞÜ (2020). Coronavirus krizi: Türkiye'nin turistik noktalarında son durum. https://www.turizmgunlugu.com/2020/03/16/coronavirus-turkiyeninturistik-noktalarina-etkisi/, Erișim tarihi: 10.04.2020.

TÜRKIYE SEYAHAT ACENTELERI BIRLIĞİ (2019). Turizm Verileri ve İstatistikler Raporu. Türkiye Seyahat Acenteleri Birliği. Erişim adresi: https://www.tursab.org.tr/istatistikler/turist-sayisi-ve-turizm-geliri, Erişim Tarihi: 10.04.2020.

TÜRKIYE OTELCILER BİRLİĞİ (2020). Mart 2020 Havalimanı İstatistikleri http://www.turob.com/tr/istatistikler, Erişim Tarihi: 10.04.2020.

ÜNLÜÖNEN, K.; TAYFUN, A. VE KILIÇLAR, A. (2009), Turizm ekonomisi, Ankara: Nobel Yayın Dağıtım.

YILDIRIM, A. ve ȘIMMȘEK, H. (2003). Sosyal bilimlerde nitel araştırma yöntemleri. Ankara: Seçkin Yayınları.

YÜKSEL, A. ve YÜKSEL, F. (2004). Turizmde bilimsel araștırma yöntemleri. Ankara: Turhan Kitabevi.

\section{Summary}

Crises, although it is undesirable to experience, suddenly break out in certain periods, leaving behind long-lasting influences on various sectors. Gulf War (1990); (2002), Tsunami disaster (2004), Madrid train attack (2004), bird flu outbreak (2005), Katrina hurricane (2005), Swine flu infestation (2006), the global economic crisis (2008-2009), the Arab Spring (2011), the military coup in Egypt (2013), the Paris terror attack (2015), the bomb attack in Brussels (2016), Syrian refugee crises (2015-2016-2017) and Coronavirus (COVID-19) have influenced tourist traffic in the world negatively. Whatever the type of outbreak, duration, power, social perception or negative meaning is, crises create a negative atmosphere in the tourism industry, which is labor-intensive sector based on trust, happy memories, different and unforgettable experiences. Tourism, a sensitive sector to the socioeconomic development level of the countries, political stability, adverse developments in the world economic conjuncture, is affected in various ways and adversely in the structural and conjunctural problems in the country. Crises in tourism are considered as a difficult period to anticipate, which suddenly reverses the current positive situation and brings about the stagnation process by creating a shock effect in destinations. In Turkey which have geographical proximity to the Middle East countries that experienced major political, economic and sociological changes, many events affecting tourism sector directly or indirectly occurred in the last 8 years. As a result of the Syrian civil war, refugee crisis, coup attempt, terrorist attacks, downing of Russian warplane by Turkey, it is seen the country lost more than 10 million tourists in 2016. Hosting important holiday destinations and tourist attraction centers and increasing the number of tourists compared to the previous year, Turkey. As a result of the disputes and tension occurred especially in the last eight years in diplomatic relations with foreign countries, Turkey experienced the period of stagnation and recession in tourism industry. From this point of view, the main purpose of this research is to reveal the characteristics of tourism and the suggestions of tourism stakeholders including alternative solutions that can be produced against the current events. In line with this aim, the tourist guides who are an important stakeholder in tourism, who play a major role in shaping the country's image in the minds of tourists are selected as sample. The qualitative research method is adopted in the exploratory study adopting a holistic multiple case pattern. The data were collected using face-to-face and asynchronous interview method from tourist guides with at least one year's experience using the criterion sampling method 
İlker Şahin, F. Özlem Güzel, “Olumsuz Güncel Gelişmelerin ve Krizlerin Türk Turizmine Etkileri: Profesyonel Turist Rehberlerinin Değerlendirmeleri ve Sektörel Çözüm Önerileri”, İstanbul Gelişim Üniversitesi Sosyal Bilimler Dergisi, 7 (2), Ekim 2020, ss. 257-280.

and the interviews were subjected to descriptive content analysis using the coding method. According to studies have become prominent themes. Practical solution proposals associated with tourism industry have been emerged in a total of 14 themes and 62 subthemes. 